\title{
Threshold Effect of Institutional Quality and the Validity of Environmental Kuznets Curve
}

\author{
Tajul Ariffin Masron ${ }^{\mathrm{a}}$ \\ Yogeeswari Subramaniam ${ }^{b}$ \\ Universiti Sains Malaysia
}

\begin{abstract}
Using a threshold estimation technique, this study examines the validity of environmental Kuznets curve (EKC) under different institutional quality regimes. A combined set of 99 developed and developing countries over the period from 2008 to 2016 has been chosen to confirm the issue in hand. Adopting panel threshold regression technique by Hansen (1999), the paper finds evidence substantiating the presence of single threshold effect. In general, we find that EKC hypothesis does not hold in the full sample analysis, in which high income fails to bring environmental degradation down. Only in the case of a segregated sample of developed countries, we find that the impact of high income (or income square) on environmental degradation is negative and significant after a certain level of ' $h i g h$ ' institutional quality has been attained. On the contrary, EKC is found to be invalid, and high income fails to be converted fully to environment-protecting activities in developing countries. Therefore, the effectiveness of income in mitigating environmental issues seems to be dampened by the poor institutional quality in developing countries.
\end{abstract}

Keywords: Environmental degradation, environmental Kuznets curve (EKC) hypothesis, institutional quality, threshold model

JEL classification: 138, 013, Q58

\section{Introduction}

In the past decade, president of the World Bank, James D. Wolfensohn has declared corruption, which is one of the important elements in institutional quality (IQ) and also known as a "cancer", poses an enormous obstacle to economic and social development and comparatively has a greater effect on both developed and developing countries (Berdiev, Kim, \& Chang, 2013). ${ }^{1}$ Based on the report of Transparency International, the score for corruption perception is measured at below 50 in about 120 countries,

\footnotetext{
School of Management, Universiti Sains Malaysia, 11800 Minden, Penang, Malaysia. Email: tams@usm.my School of Management, Universiti Sains Malaysia, 11800 Minden, Penang, Malaysia. Email: yogees.wari@ yahoo.com.my (Corresponding author)

1 To our understanding and after deep consideration on various elements representing institutional quality, such as government effectiveness, rule of law, regulatory quality and corruption (as outlined by the World Bank under Worldwide Governance Indicators database); although they could be defined differently, corruption is a good reflection of low government effectiveness, unclear rule of law as well as poor regulatory quality. Hence, the discussion in the introduction section is focusing on corruption as the only case that can be easily understood and also able to conserve space.
} 
at the scale 0 for highly corrupted countries to 100 for less corrupted ones (RoseAckerman \& Palifka, 2016). According to the report, corruption is not only prevalent in developing countries but even in developed countries. In this context, corruption has been identified as the main culprit that undermines growth and economic development (Del Monte \& Papagni, 2001; Mauro, 1998; Ugur, 2014; Ugur \& Dasgupta, 2011). Theoretically, it follows "sand in the wheels" hypothesis which postulates that corruption impedes growth and development because it entails resource misallocation and raises transaction costs (Aidt, 2009). This postulates that high levels of corruption tend to reduce the effectiveness of industrial policies and encourage businesses to operate in the unofficial sector to avoid tax and costly regulatory laws (Ampratwum, 2008). In turn, it tends to depress private and public investment by reducing its profitability and certainty (Ampratwum, 2008).

However, corruption also causes serious environmental degradation (Robbins, 2000). It is generally believed that corruption leads to the loss of natural resources, ecosystem and biodiversity, contributing to negative effects on the environment and the environment-dependent communities. Corruption affects environment degradation by embezzlement of funds allocated for environmental protection programme to private pockets (Winbourne, 2002). In addition, bribery in environmental inspections and the permitted system further exacerbates natural resource depletion, environmental pollution and the trafficking of wildlife and other natural resources (Dillon et al., 2006). Bribery assists over-extraction of natural resources, poaching of rhinos, elephants for ivory and tigers for their skin and bones and also illegal logging of timber in tropical forest reserves (Pellegrini \& Gerlagh, 2006; Welsch, 2004). Moreover, under the joint implementation (JI) scheme of the United Nations Framework Convention on Climate Change (UNFCCC) around 600 million tons of carbon was wrongly emitted, which was hit by serious corruption allegations involving organised crime in Russia and Ukraine (Zhang, Jin, Chevallier, \& Shen, 2016). Hence, there can be a point of irreversible environmental damages or risks if the countries are poor in governance, ${ }^{2}$ and suffers due to the high level of corruption.

Table 1 clearly indicates the top ten ranked nations perceived to be the least corrupted and most corrupted countries in year 2016. Somalia, South Sudan, North Korea and Syria are perceived to be the most corrupted countries in the world. There is a widely accepted view that for the past ten years, Somalia has retained the undesirable heading as world's 'most corrupted' with a score of 10 on the corruption perception index. Fourth from the bottom is Syria, a war-torn country which is presently seeing a massive outflow of refugees (Banta, 2008). Although Germany and Canada are classified among the top 10 cleanest countries in the world in terms of corruption index, the scores that merely surpass 80 indicate that corruption is somehow taking place and could be serious in the eyes of developed countries. Hence, Table 1 clearly indicates that corruption is not an exclusive feature of developing countries but also in every country in the world although it is generally low in developed countries. Moreover, it is generally believed that those with high corruption tend to score badly in terms of

2 Governance and institutional quality could have distinct meanings, but in this study, we treat both as similar. They are used interchangeably. 
Threshold Effect of Institutional Quality and the Validity of Environmental Kuznets Curve

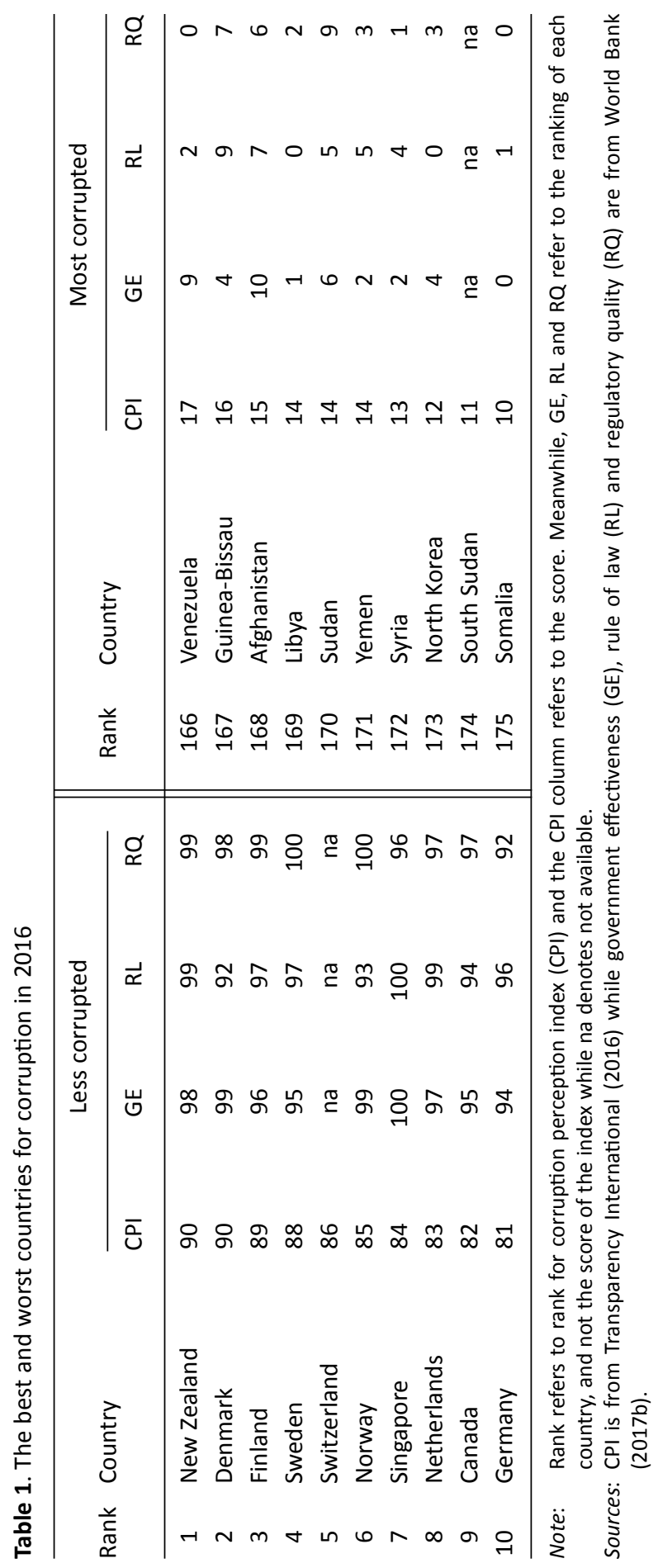


other institutional elements such as government effectiveness (GE), rule of law (RL) and regulatory quality (RQ), as shown in Table 1 . None of the most corrupted countries are capable to be above 10th place in the ranking for $G E, R L$ and $R Q$.

Although the corruption indices in Germany, Canada and Netherlands are far better than Somalia, South Sudan and North Korea, the relatively low corruption indices may still open the door widely for pollution to occur by persons or firms in the countries. Comparing Figure 1 and Figure 2, the most corrupted countries within both groups share the same point, which is the largest polluter in each group. Coincidentally, the second and third worse countries in both groups are also ranked as the second and third most polluted countries in each group. On this basis, no country in the world is pollution-free although some are less corrupted than others. Transparency International (2016) states that people are often faced with bribery and extort situations in lower-scale countries and are reliant on basic services which are undermined by the misappropriation of funds while seeking redress of authorities in charge. Although it seems less evident in the everyday lives of citizens in higher-ranking nations, closeddoor deals, illicit finance and patchy law enforcement exacerbate many forms of corruption at home and abroad (Transparency International, 2016).

In view of the above, there is a growing consensus that institutional quality (IQ) can have a strong effect on environmental outcomes and actions. According to Bhattarai and Hammig (2004) and Rodrik, Subramanian and Trebbi (2004), regardless of developed or developing countries, better IQ contributes to good environmental outcomes by being a solution to maintain the collective action, and solve environmental problems and unsustainable use of natural resources. For instance, in South Africa, the new Air Quality Act (2004) which replaced the ineffective Atmospheric Pollution Prevention Act (1965) provides more comprehensive decision-making and management for air pollution. Thereafter, South Africa is not only conducive to a good environmental quality; it also reduces the burden of health impact associated with polluted ambient air (Kotze, 2006).

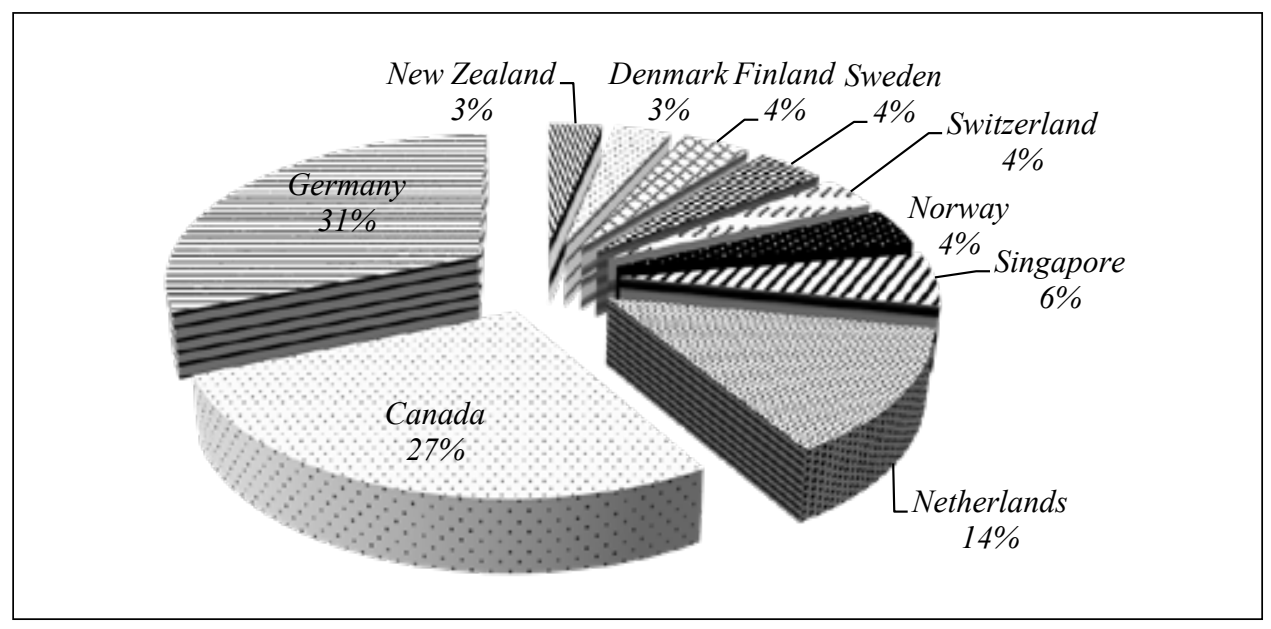

Figure 1. $\mathrm{CO}_{2}$ emissions per capita (in the perceived as less corrupted countries) Source: World Bank (2017a). 


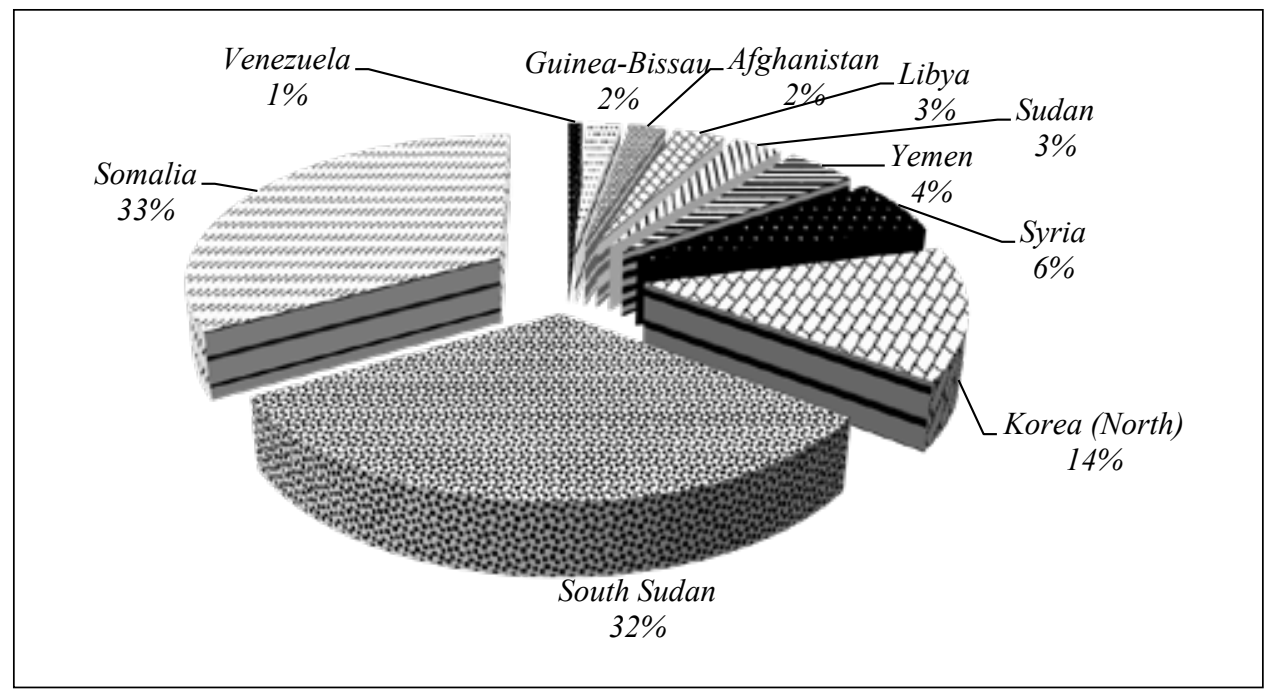

Figure 2. $\mathrm{CO}_{2}$ emissions per capita (in the perceived as most corrupted countries) Source: World Bank (2017a).

However, weak institutional quality may constrain the outcomes of environmental efforts by escalating environmental degradation, such as trade in endangered species, deforestation and ozone depletion. In response to these statements, weak IQ contributes to the development of environmentally damaging policies and unfair allocation of environmental resources that contribute to environmentally harmful practices. For example, India has a number of environmental policies on Water Act of 1974 and Air Act of 1981 to deal with increasingly hazardous pollution levels (Chen \& Lees, 2018). However, these regulations have not been positive in terms of their effectiveness. Thus, if institutions are weak or less effective, then the desire to ignore environmental quality will be higher.

The EKC hypothesis states that as a country enjoys high income level, environmental quality can automatically be protected (or improved as reflected in lower environmental degradation). Based on the experience of several developed countries as depicted in Figure 1 as well as developing countries as shown in Figure 2, EKC hypothesis is unlikely to hold. Although developed countries are becoming high-income countries, their successes are accompanied by growing amounts of emission in the same path to emissions faced by developing countries. In other words, we suspect that the effectiveness of high income in mitigating environmental pollution could have been undermined by poor institutional quality. Simple correlation shows that the biggest polluters are countries such as Germany, Canada and the Netherlands for developed countries (see Figure 1), as well as Somalia, South Sudan and North Korea (see Figure 2) for countries with the lowest corruption index (see Table 1). To further find support, Figure 3 offers a firsthand insight of the issue that EKC relationship may not hold for both developing and developed countries. Therefore, we predict that the validity of EKC is subject to the level of institutional quality. 

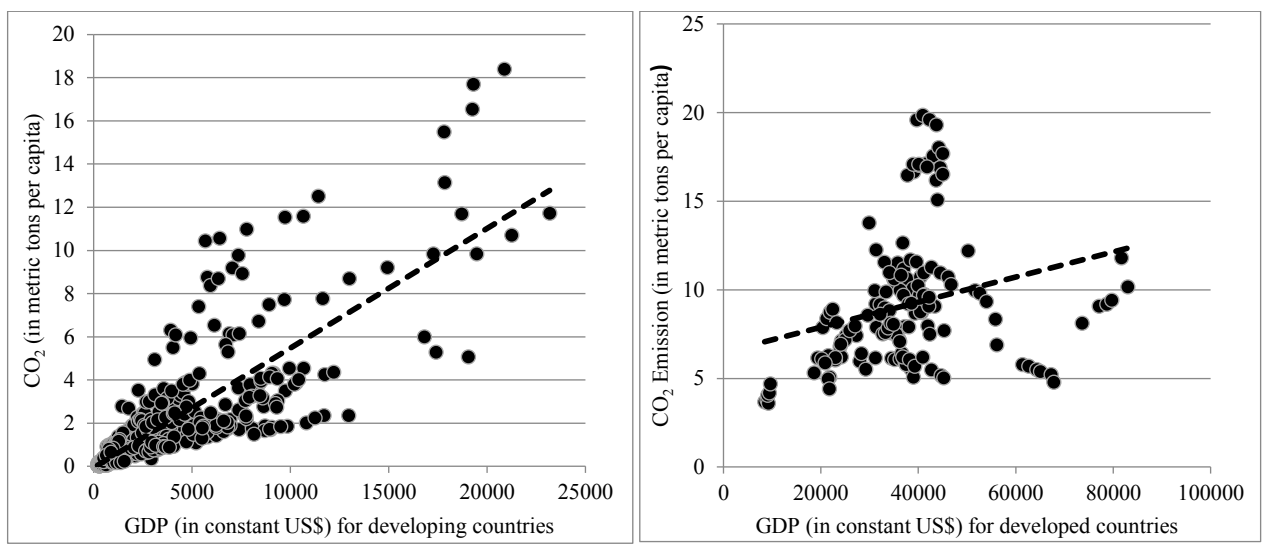

Figure 3. $\mathrm{CO}_{2}$ emission vs GDP of 50 developing and developed countries Note: The upward line represents the simple regression line. Source: World Bank (2017a).

The remainder of the paper is organised as follows. The related literature is briefly reviewed in section 2 . The model construction and methodology are outlined in section 3. The empirical results are presented in section 4 and finally, section 5 concludes the study.

\section{Literature Review}

This section is reserved to demonstrate the research gap as well as the appropriate model to be employed. We start this section by discussing several factors that have been confirmed by past studies as critical to environmental quality.

(a) Renewable Energy and Environmental Pollution

Firstly, the role of renewable energy in environmental pollution has been considered as one of the essential principles in green economics. Renewable energy or also known as a subset of "green power" provides the highest environmental benefit by reducing the emission as opposed to non-renewable energy. A number of studies in this context have found that renewable energy can help reduce environmental pollution and enhance environmental quality (Al-Mulali \& Ozturk, 2016; Belaid \& Youssef, 2017; Bento \& Moutinho, 2016; Bilgili, Kocak, \& Bulut, 2016; Dogan \& Seker, 2016; Jebli, Youssef, \& Ozturk, 2016; Zoundi, 2017). For instance, the adoption of renewable energy sources of solar, wind, geothermal, hydropower and biomass also contribute to improve energy efficiency and also provide sustainable energy services (Elum \& Momodu, 2017). Hence, according to the analysis by Elum and Momodu (2017), a transition to renewable energy could reduce emission levels and offer access to sustainable energy to millions of people worldwide. However, Apergis, Payne, Menyah and Wolde-Rufael (2010) and Boluk and Mert (2014) show that increasing renewable energy consumption increases carbon emission for a panel of European Union countries, developed and developing 
countries. This is largely due to the low price of natural gas which makes renewable energy less attractive compared to natural gas-fuelled generation (Apergis et al., 2010). In addition, it is possible that many countries may not have reached the threshold point of high production of renewable energy to the point where renewable energy can start to mitigate carbon emission level (Apergis et al., 2010).

\section{(b) Foreign Direct Investment and Environmental Pollution}

There is also a growing literature that is interested in studying the effect of foreign direct investment (FDI) on environmental pollution, which can be divided into two clusters. The first cluster is related to pollution haven hypothesis (Cole \& Elliot, 2005; Lau, Choong, \& Eng, 2014; Lee \& Lee, 2009; Shahbaz, Nasreen, Ahmed, \& Hammoudeh, 2017; Zhang \& Zhou, 2016). This hypothesis points out that those multinational firms engaged in highly polluting activities have relocated their production to countries with lower environmental regulation to circumvent the cost of environmental control in their home countries. Countries with high environmental regulations or mainly known as developed countries will lose all the dirty industries and poor developing countries will get them all. On the contrary, the second cluster is related to the pollution halo hypothesis (see Cheung \& Lin, 2004; Mielnik \& Goldemberg, 2002; Stretesky \& Lynch, 2009; Zugravu-Soilita, 2017). One of the explanations to pollution halo hypothesis is that multinational firms will lead to the transference of clean and environmentally friendly technology in the hosting countries. This further implies that increases in FDI inflows are likely to improve R\&D techniques and, thereby, induce higher energy efficiency and eventually lead to less environmental pollutions. As a result, it seems that the relationship between FDI and environmental pollutions has appeared to be inconsistent until now, and further analysis, especially at the country level, might be necessary.

\section{(c) Trade and Environmental Pollution}

Thirdly, we observe that trade plays an important role in affecting environmental pollution. It is worth noting that an increase in trade can affect environmental pollutions through three independent effects, namely scale, technique and composition (Aklin, 2016; Copeland \& Taylor, 1995; Dasgupta, Laplante, Wang, \& Wheeler, 2002; Grossman \& Krueger, 1995; Halicioglu \& Ketenci, 2016; Kellenberg, 2009; Reppelin-Hill, 1999; Shahbaz et al., 2017). In the scale effect, an increase in trade may contribute to higher energy consumption and higher production, where it will lead to a substantial rise in environmental pollutions. The composition effect is based on changes in the structure of the economy (Lau et al., 2014; Rezek \& Rogers, 2008). Thus, it can be argued that trade tends to improve environmental quality as the structure of the economy changes from industrialisation to services and information-technology intensive industry (Lau et al., 2014). Lastly, technique effect refers to the technology spillover through trade flows among countries, and the adaptation of environmental-friendly technologies in producing goods that can lead to environmental improvement (Aklin, 2016; Dogan \& Seker, 2016; Reppelin-Hill, 1999). More importantly, trade can allow access to new technology which is more environmentally efficient to local production by reducing the use of inputs such as energy, water and other environmentally hazardous substances. 
(d) Population Growth and Environmental Pollution

The fourth strand of research focuses on the environmental degradation and population growth. There are a number of studies in this context including studies by Stern (2004) for global, Liddle and Lung (2010) for developed countries, Hossain (2011) for newly industrialised countries, Zhang and Lin (2012) for the United States, Hafeez, Chunhui, Strohmaier, Ahmed and Jie (2018) for One Belt and One Road Initiative (OBORI) countries, Paramati, Alam and Lau (2018) for developed and emerging market economies and a few others. One observation from the related literature states that population growth has an impact on the environmental quality through the consumption of natural resources and production of resources. The consumption of natural resources increases pressure on marginal lands, over-exploitation of soils, soil erosion and flooding. As a result, Hafeez et al. (2018), Hossain (2011), Liddle and Lung (2010), Paramati et al. (2018), and Zhang and Lin (2012) revealed that population growth has been often conjectured to have a negative effect on environmental quality.

\section{(e) Urbanisation and Environmental Pollution}

Al-Mulali and Ozturk (2016), Hossain (2011), Liu and Bae (2018), Marquart-Pyatt (2004), Munir and Ameer (2018), Shahbaz et al. (2017) and Zhang and Zhou (2016) examined the effect of urbanisation on environmental quality. In the case of urbanisation, as people migrate from rural areas to urban areas in search of education, better jobs and living standards, they exert pressure on urban environment and resources (AlMulali \& Ozturk, 2016; Shahbaz et al., 2017). This leads to more degradation. Overall, these empirical evidences seem to be almost similar, suggesting that urbanisation has statistically significant negative effect on environmental degradation.

\section{(f) Economic Growth and Environmental Pollution}

Over the past two decades, the literature on economic growth and environmental pollution has been intensively analysed in both developed and developing countries. However, close observation of past studies reveals that most of the past interest is mainly on testing income-environmental degradation nexus. In other words, most of them are interested in examining the existence of EKC in OECD countries (Jebli et al., 2016; Shafiei \& Salim, 2014), MENA countries (Omri, Daly, Rault, \& Chaibi, 2015), ASEAN countries (Heidari, Katircioğlu, \& Saeidpour, 2015; Lean \& Smyth, 2010; Saboori, Sulaiman, \& Mohd, 2012), low, middle and high-income countries (Roberts \& Grimes, 1997) and developing and developed countries (Ehrhardt-Martinez, Crenshaw, \& Jenkins, 2003; Sari \& Soytas, 2007; Shandra, London, Whooley, \& Williamson, 2004; Sharma, 2011). EKC is essentially about environmental pollution level, which rises as a country is at the initial stage of economic development or at low income level. Yet, the empirical evidences still find mixed support for the existence of EKC. Some empirical results demonstrate varied relationships that exist between environmental pollution and economic growth such as linear (Ang, 2007), U-shaped (Begum, Sohag, Abdullah, \& Jaafar, 2015), inverted U-shaped (Pao \& Tsai, 2011; Roberts \& Grimes, 1997; Sabooori et al., 2012; Shandra et al., 2004), N-shaped (Grossman \& Krueger, 1995; Shafik, 1994) and monotonic shaped (Holtz-Eakin \& Selden, 1995). Therefore, the findings of these studies 
appear to be contradictory or inconsistent. One potential answer to this inconsistency could be due to the forgotten fact that all countries in the world are suffering from imperfect institutional quality. Accordingly, the contribution of this study is to quantify the effect of income on environmental degradation under different regimes (or level) of IQ. This conjecture requires a flexible modeling strategy that can accommodate different kinds of income and environmental degradation interactions. From this point of view, we hypothesise that the income-environment relationship may be contingent on institutional quality, where increase in income may improve environmental quality after institutional quality exceeds a certain high threshold level.

\section{Methodology}

The empirical model of this paper is derived from the following standard EKC function which can be displayed as follows: ${ }^{3}$

$$
\frac{\partial E D_{t}}{\partial_{t}}=\alpha\left(y-y^{*}\right) g
$$

where Equation (1) is the change of environmental degradation (ED) at year $(t)$ which is a function of the growth rate $(g)$ and the distance of income $(y)$ to the turning point $\left(y^{*}\right)$. If $g$ and coefficient $(\alpha)$ are positive and negative, respectively, the rate of change of environmental degradation can be either $\frac{\partial E D_{t}}{\partial_{t}}>0$ when $y<y^{*}$, or $\frac{\partial E D_{t}}{\partial_{t}}<0$ when $y>y^{*}$. This describes an inverted U-shaped relationship between environmental degradation and income where degradation increases until income level $y^{*}$ is reached and decreases thereafter. Integrating Equation (1) with respect to time and taking the income measure and the growth rate as a constant, we obtain the following equation:

$$
E D_{t}=\mu+\alpha\left(y-y^{*}\right) g t
$$

where $\mu$ is a constant of integration. Accordingly, we extend Equation (2) by incorporating the individual-specific effects $\left(\mu_{i}\right)$, covariates $\left(Z_{i t}\right)$, and stochastic error term $\left(\varepsilon_{i t}\right)$. Namely,

$$
\begin{aligned}
E D_{i t} & =\mu_{i}+\alpha\left(y_{i}-y^{*}\right) g_{i} t+\bar{\beta}^{\prime} Z_{i t}+\varepsilon_{i t} \\
& =\mu_{i}+\alpha\left(y_{i} g_{i} t\right)+\alpha y^{*}\left(g_{i} t\right)+\bar{\beta}^{\prime} Z_{i t}+\varepsilon_{i t} \\
& =\mu_{i}+\beta_{0}\left(y_{i} g_{i} t\right)+\beta_{1}\left(g_{i} t\right)+\bar{\beta}^{\prime} Z_{i t}+\varepsilon_{i t}
\end{aligned}
$$

Notice that $\alpha=\beta_{0}$ and $y^{*}=\beta_{1} / \beta_{0}$, where $i=1,2, \ldots, N$ denotes the country and $t=1,2, \ldots, T$ denotes the time period. $E D$ is environmental degradation, $y$ and $g$ are measures of income $(G D P)$ and quadratic income $\left(G D P^{2}\right)$, respectively. Hence, we specify the following econometric model and estimate the following in logarithmic form:

$$
E D_{i t}=\mu_{i}+\beta_{0} G D P_{i t}+\beta_{1} G D P_{i t}^{2}+\beta_{2} R E_{i t}+\varepsilon_{i t}
$$

3 Stern (2004) and Leitão (2010). 
We take Equation (4) as a baseline specification, where $R E$ is renewable energy and $\beta_{0}$, $\beta_{1}$, and $\beta_{2}$ are the coefficients of the relevant variables to be estimated.

To test the hypothesis regarding the influence of institutional quality (IQ) on the impact of income in environmental degradation, we extend Equation (4) by applying the panel threshold regression approach suggested by Hansen (1999). The panel threshold regression autoregressive model developed by Hansen (1999) is based on static framework. Thus, the model takes the following form:

$$
\begin{aligned}
E D_{i t}= & \mu_{i}+\beta_{0} G D P_{i t}+\beta_{1} G D P_{i t}^{2} I\left(I Q_{i t} \leq \gamma\right)+\beta_{2} G D P_{i t}^{2} I\left(I Q_{i t}>\gamma\right)+ \\
& \beta_{3} R E_{i t}+\varepsilon_{i t}
\end{aligned}
$$

where $I Q$ is the threshold variable, $I($.$) is the indicator function indicating the regime$ defined by the threshold variable. The threshold model in Equation (5) can also be rewritten as:

$$
E D_{i t}=\mu_{i}+\beta^{\prime} G D P_{i t}^{2}(\gamma)+\varepsilon_{i t}
$$

$\gamma$ and $G D P^{2}$ is threshold and quadratic income, respectively and $\beta=(\beta 1 \beta 2)^{\prime}$. As the first step, least square is used to eliminate the individual specific effect. Taking averages of Equation (6) over time $(t)$ produces the following equation:

$$
\overline{E D_{i}}=\mu_{i}+\beta^{\prime} \overline{G D P}_{i}^{2}(\gamma)+\bar{\varepsilon}_{l}
$$

where $\overline{E D_{i}}=T^{-1} \sum_{t=1}^{T} E D_{i t}, \overline{\varepsilon_{l}}=T^{-1} \sum_{t=1}^{T} \varepsilon_{i t}$ and $\overline{G D P_{i}^{2}}(\gamma)=\frac{1}{T} \sum_{t=1}^{T} G D P_{i t}^{2}(\gamma)$

$=\left(\begin{array}{c}\frac{1}{T} \sum_{t=1}^{T} G D P_{i t}^{2} I\left(I Q_{i t} \leq \gamma\right) \\ \frac{1}{T} \sum_{t=1}^{T} G D P_{i t}^{2} I\left(I Q_{i t}>\gamma\right)\end{array}\right)$

Taking the difference between Equations (6) and (7) creates:

$$
E D^{*}{ }_{i t}=\beta^{\prime} G D P_{i t}^{2 *}(\gamma)+\varepsilon_{i t}^{*}
$$

where $E D_{i t}^{*}=E D_{i t}-\overline{E D_{i}}, G D P_{i t}^{2 *}(\gamma)=G D P_{i t}^{2}(\gamma)-\overline{G D P_{i}^{2}}(\gamma)$, and $\varepsilon_{i t}{ }^{*}=\varepsilon_{i t}-\overline{\varepsilon_{i}}$.

Let $E D_{i}^{*}=\left[\begin{array}{c}E D_{i 2}^{*} \\ \vdots \\ E D_{i T}^{*}\end{array}\right], \quad G D P_{i}^{2 *}(\gamma)=\left[\begin{array}{c}G D P_{i 2}^{2 *}(\gamma)^{\prime} \\ \vdots \\ G D P_{i T}^{2 *}(\gamma)^{\prime}\end{array}\right], \quad \varepsilon_{i}{ }^{*}=\left[\begin{array}{c}\varepsilon_{i 2}{ }^{*} \\ \vdots \\ \varepsilon_{i T}{ }^{*}\end{array}\right]$

denote the stacked data and errors for an individual with one time period deleted. Then, let $E D^{*}, G D P^{2 *}(\gamma)$ and $\varepsilon^{*}$ denote the data stacked over all individuals, for example

$$
G D P^{2 *}(\gamma)=\left[\begin{array}{c}
G D P_{1}^{2 *}(\gamma) \\
\vdots \\
G D P_{i}^{2 *}(\gamma) \\
\vdots \\
G D P_{n}^{2 *}(\gamma)
\end{array}\right]
$$


Using this notation, Equation (8) is equivalent to

$$
E D^{*}=G D P^{2 *}(\gamma) \beta+\varepsilon^{*}
$$

For given $\gamma$, the slope of coefficient $\beta$ can be estimated by ordinary least squares (OLS). The estimated equations are given by:

$$
\hat{\beta}(\gamma)=\left(G D P^{2 *}(\gamma)^{\prime} G D P^{2 *}(\gamma)\right)^{-1} G D P^{2 *}(\gamma) E D^{*}
$$

The vector of regression residuals is defined as:

$$
\widehat{\varepsilon}^{*}(\gamma)=E D^{*}-G D P^{2 *}(\gamma) \hat{\beta}(\gamma)
$$

and the sum of squared error as:

$$
\begin{aligned}
S_{1}(\gamma) & =\widehat{\varepsilon}^{*}(\gamma)^{\prime} \widehat{\varepsilon}^{*}(\gamma) \\
& =E D^{*}\left(1-G D P^{2 *}(\gamma)^{\prime}\left(G D P^{2 *}(\gamma)^{\prime} G D P^{2 *}(\gamma)\right)^{-1} G D P^{2 *}(\gamma)^{\prime}\right) E D^{*}
\end{aligned}
$$

Hansen (1999) recommends estimating $\gamma$ using least squares in order to minimise the sum of squared errors. Thus, the least squares estimators of $\gamma$ is:

$$
\hat{\gamma}=\underset{\gamma}{\operatorname{argmin} S_{1}(\gamma)}
$$

Once $\hat{\gamma}$ is obtained, the slope coefficient estimate is $\hat{\beta}=\hat{\beta}(\hat{\gamma})$. The residual is $\widehat{\varepsilon}^{*}=\widehat{\varepsilon}^{*}(\hat{\gamma})$ and residual variance is $\hat{\sigma}^{2}=\frac{1}{n(T-1)} \widehat{\varepsilon}^{* \prime} \widehat{\varepsilon}^{*}=\frac{1}{n(T-1)} S_{1}(\hat{\gamma})$.

In the testing procedure, the null hypothesis of no threshold effect or $H_{0}: \beta_{1}=\beta_{2}$ is tested by using the likelihood ratio test:

$$
F_{1}=\left(S_{0}-S_{1}(\hat{\gamma})\right) / \hat{\sigma}^{2}
$$

where $S_{0}$ and $S_{1}(\hat{\gamma})$ are sum of squared errors for the null hypothesis and alternative hypothesis, respectively. Since the asymptotic distribution of $F_{1}$ is non-standard, Hansen (1999) suggests a bootstrap procedure to stimulate the asymptotic distribution of likelihood ratio test. If $p$-value is less than the desired critical value, the null hypothesis of no threshold effect is rejected.

When there is a threshold effect $\left(\beta_{1} \neq \beta_{2}\right)$ Hansen (1999) has shown that $\hat{\gamma}$ is consistent for $\gamma_{0}$ (true value of $\gamma$ ). The asymptotic distribution of threshold estimate is tested with the null hypothesis of $H_{0}: \gamma=\gamma_{0}$, using the likelihood ratio test of:

$$
L R_{1}(\gamma)=\left(S_{1}(\gamma)-S_{1}(\hat{\gamma})\right) / \hat{\sigma}^{2}
$$

The asymptotic confidence interval is shown as $c(\beta)=-2 \log (1-\sqrt{1-\beta})$, where for a given asymptotic level $\beta$, the null hypothesis of $H_{0}: \gamma=\gamma_{0}$ is rejected if $L R_{1}(\gamma)$ exceeds $c(\beta)$. 
For the double threshold, the model is modified as:

$$
\begin{aligned}
E D_{i t}= & \mu_{i}+\beta_{0} G D P_{i t}+\beta_{1} G D P_{i t}^{2} I\left(I Q_{i t} \leq \gamma_{1}\right)+\beta_{2} G D P_{i t}^{2} I\left(\gamma_{1}<I Q_{i t} \leq \gamma_{2}\right)+ \\
& \beta_{3} G D P_{i t}^{2} I\left(\gamma<I Q_{i t}\right)+\beta_{4} R E_{i t}+\varepsilon_{i t}
\end{aligned}
$$

where the threshold value is $\gamma_{1}<\gamma_{2}$.

While the specification in Equation (4) based on the synthesis of environmental degradation-income literature, several other control variables have also been considered for robustness test. Thus, we add foreign direct investment (Lau et al., 2014; Zhang \& Zhou, 2016), population growth (Hossain, 2011; Zhang and Lin, 2012; Hafeez et al., 2018; Paramati et al., 2018), urbanization (Al-Mulali and Ozturk, 2016; Zhang and Zhou, 2016; Munir and Ameer, 2018; Liu and Bae, 2018) and trade (Lau et al., 2014; Rezek \& Rogers, 2008) to the baseline specification for robustness check.

\subsection{Data}

This study employs a panel sample of 99 countries ( 25 developed countries and 74 developing countries) for the period from 2008-2016. For the measurement of each variable, environmental degradation (ED) is represented by carbon dioxide emission (in metric tons per capita), GDP is represented by per capita real GDP (in constant 2000 US\$), FDI is proxied by foreign direct investment as \% of GDP, trade (TR) is represented by trade as \% of GDP, renewable energy (RE) is proxied by percentage of renewable energy out of total final energy consumption, population (POP) is measured by population growth and urbanisation (URB) is measured by percentage of urban population of the total population. All information is downloaded from the World Development Indicators (World Bank, 2017a). Besides that, the present analysis makes use of the four measures of institutional quality (IQ), namely control of corruption (CC), government effectiveness $(G E)$, regulatory quality $(R Q)$, rule of law $(R L)$ and finally, average institutional quality $\left(I_{A V G}\right)$ as a proxy for aggregate $I Q$. The $I Q_{A V G}$ is obtained by averaging the four indices. ${ }^{4}$ The datasets are collected from the Worldwide Governance Indicators (World Bank, 2017b).

\section{Empirical Results}

Table 2 presents the descriptive statistics of the variables used in our estimation. The summary of the common statistics contains the means, minimum and maximum values of each series before transforming into the logarithmic form. The highest level of

\footnotetext{
4 We construct IQ (=IQAVG) based on only four of the most relevant factors to environmental degradation. Voice and accountability (VA) as well as political stability (PS) are not predicted to be directly relevant to environmental issues. In other words, VA and PS may influence environmental quality but most likely to get through government effectiveness, rule of law and regulatory quality. Of course, this argument is still open for debate but this study opts for this option. While all six elements are as suggested by the World Bank (2017b), we also plan to include other potential proxies such as democracy. However, this effort is either hampered by similar argument as the case of VA and PS, or data unavailability for the sample of countries that we want to study. Specifically, data for democracy is not fully available for all countries included in this study. Hence, we leave it for future research.
} 
Threshold Effect of Institutional Quality and the Validity of Environmental Kuznets Curve

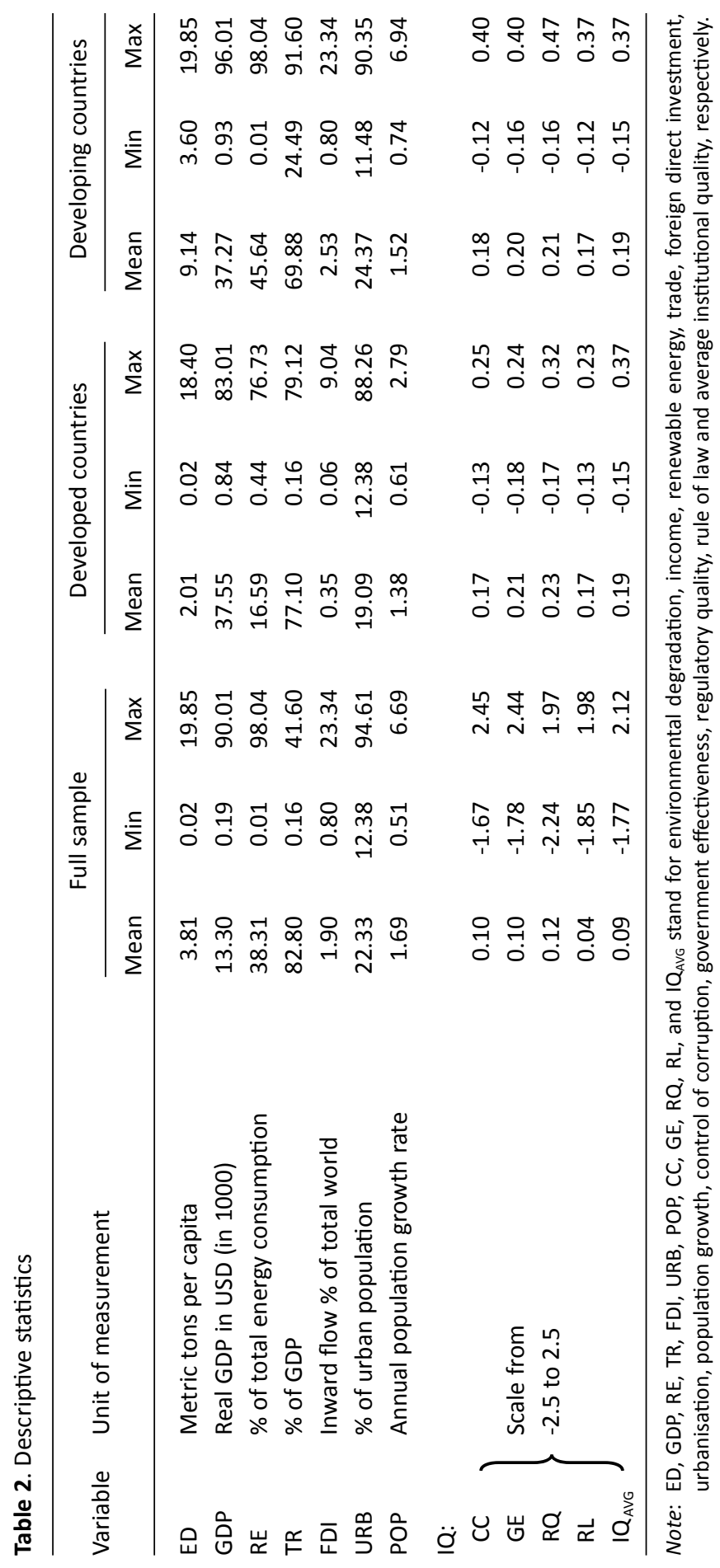


Tajul Ariffin Masron and Yogeeswari Subramaniam

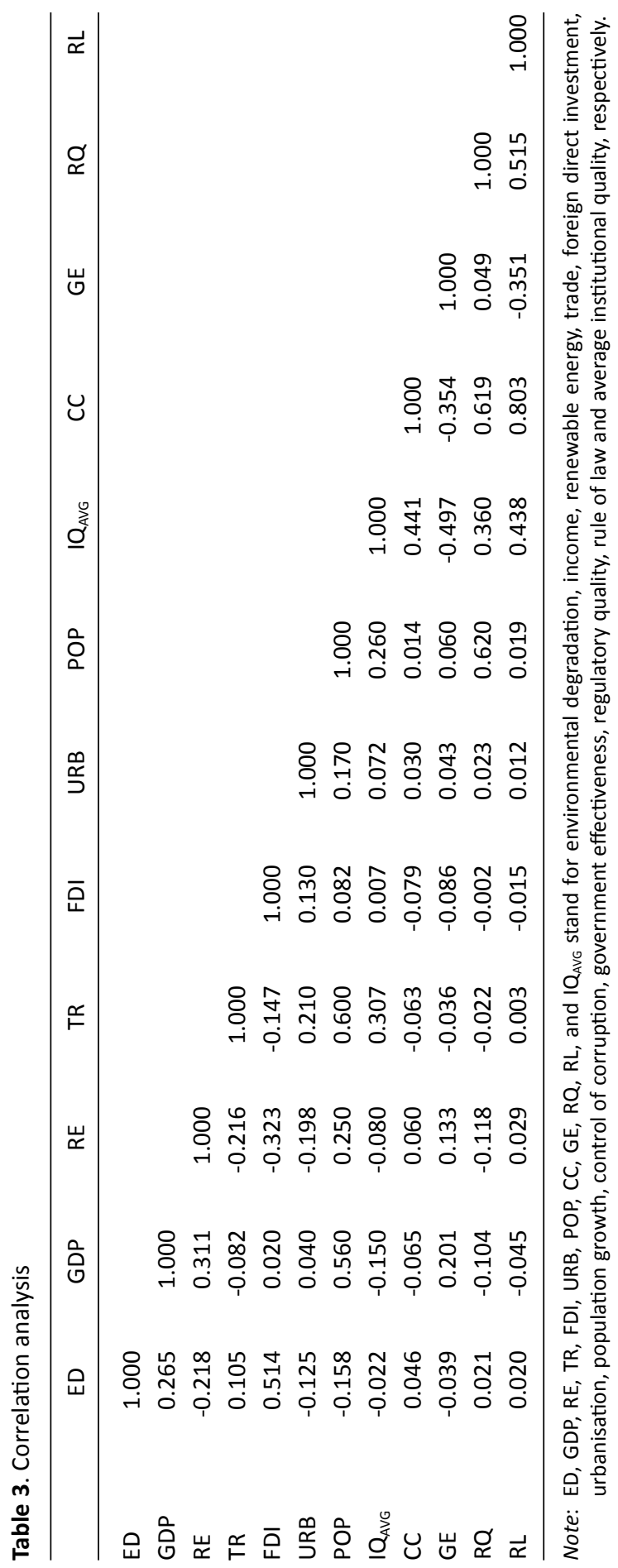


environmental degradation (19.85 metric tons in 2009) is in the United States while the lowest level is in Congo (0.02 metric tons in 2010). Regarding the level of per capita real GDP, Norway has the highest level with USD90008.8 in 2011, whereas Ethiopia has the lowest level with USD194.926 in 2008. Congo has the highest level of consumption of renewable energy (98.041\%) in 2013 and the country with the lowest consumption of renewable energy is Saudi Arabia with $0.007 \%$ in 2013 . Most importantly, from Table 2, we find that the mean of ED recorded the highest for developing countries followed by developed countries at 9.14 and 2.01 metric tons per capita, respectively. This implies that countries in the early stage of growth such as those from the developing countries are generally more polluted.

Table 3 displays the results of correlation matrix of the key variables. As expected, ED has a strong positive correlation with GDP, FDI and TR which weakly supports the existing literature that GDP, FDI and TR are determinants of ED. On the other hand, RE, $I Q_{A V G}, G E, U R B$ and POP are negatively related to ED as expected.

Table 4 reports the estimation results of the threshold effects using five institutional quality variables, namely IQAVG, CC, GE, RQ and RL. The statistical significance of the threshold effect is evaluated by F-statistics with bootstrap p-values for the single and double thresholds. Referring to model 1 , where institutional quality is measured as the average of IQ $\left(\mathrm{IQ}_{\mathrm{AvG}}\right)$, the point estimate of the single threshold value is 0.173 with F-statistics of 42.63. The F-statistics shows that the single threshold is significant at least at $10 \%$ and higher than the critical value of 22.166. On the other hand, the test for a double threshold $F_{2}$ is not statistically significant, with a bootstrap p-value of 0.753 . Thus, we conclude that there is strong evidence of single threshold in the regression relationships.

Table 4. Tests for threshold effect

\begin{tabular}{|c|c|c|c|c|c|}
\hline & $\begin{array}{l}\text { Model } 1 \\
I Q=I Q_{A V G}\end{array}$ & $\begin{array}{c}\text { Model } 2 \\
\mathrm{IQ}=\mathrm{CC}\end{array}$ & $\begin{array}{c}\text { Model } 3 \\
I Q=G E\end{array}$ & $\begin{array}{c}\text { Model } 4 \\
\mathrm{IQ}=\mathrm{RQ}\end{array}$ & $\begin{array}{c}\text { Model } 5 \\
\text { IQ }=\text { RL }\end{array}$ \\
\hline & \multicolumn{5}{|c|}{ Test for Single Threshold } \\
\hline Threshold 1 & 0.173 & 0.142 & 0.196 & 0.196 & 0.148 \\
\hline $\mathrm{F}_{1}$ & 42.63 & 40.23 & 33.04 & 22.41 & 46.69 \\
\hline$p$-value & $0.043 * *$ & $0.027 * *$ & $0.060 * *$ & $0.046 * *$ & $0.060 * *$ \\
\hline \multirow[t]{2}{*}{$10 \%$ Critical value } & 22.166 & 22.674 & 21.801 & 17.202 & 24.028 \\
\hline & \multicolumn{5}{|c|}{ Test for Double Threshold } \\
\hline Threshold 2 & 0.172 & 0.138 & 0.189 & 0.188 & 0.147 \\
\hline Threshold 1 & 0.173 & 0.142 & 0.196 & 0.196 & 0.148 \\
\hline $\mathrm{F}_{2}$ & 21.36 & 20.74 & 24.60 & 21.60 & 23.34 \\
\hline$p$-value & 0.753 & 0.133 & 0.110 & 0.113 & 0.103 \\
\hline $10 \%$ Critical value & 40.529 & 22.743 & 25.415 & 27.392 & 24.101 \\
\hline
\end{tabular}

Note: ** denotes significance of at least at $10 \%$ critical value. CC, GE, RQ, RL, and $\mathrm{IQ}_{\mathrm{AvG}}$ stand for control of corruption, government effectiveness, regulatory quality, rule of law and average institutional quality, respectively. 
Model 2 presents the results of the repeated analysis, which used CC as an alternative proxy for institutional quality. We find that the test for a single threshold $F_{1}(40.23)$ is significant with the bootstrap p-value of 0.027 , and the test for a double threshold $F_{2}(20.74)$ is insignificant, with a bootstrap $p$-value of 0.133 . The key assumption here is that there is evidence of single threshold effect of CC on GDP2. Moving on to Models 3 and 4, where the institutional quality proxies are GE and RQ, the estimated threshold values are 0.196 for both proxies. Again, the test statistics of $F_{1}$ shows that a single threshold exists for both indicators, with bootstrap $p$-values of 0.060 and 0.046 , respectively. However, the tests for double threshold are insignificant. Model 5 reports the result for the model using another institutional indicator, which is RL. The single threshold of 46.69 is statistically significant at $10 \%$ with bootstrap p-value of 0.060 . However, the test for double threshold $F_{2}$ is insignificant with the bootstrap p-value of 0.103 . Thus, we can firmly conclude that there is strong evidence of single threshold in all models. Hence, for the remainder of the analyses, we worked with the single threshold model.

Having established the existence of an institutional quality threshold, the next question will be on how income affects environmental degradation. Table 5 presents the estimated results. In all five models, the coefficients of income and renewable energy are statistically significant and consistent with the theory. The estimated coefficient of income (GDP) is positive and is a significant determinant of environmental degradation at $1 \%$. Interestingly, this finding confirms that income at the early stage contribute to increment in environmental pollution. Renewable energy (RE) is negative and statistically significant in promoting "green power" that provides the highest environmental benefit by reducing the emissions. The adoption of renewable energy sources such biomass, wind, solar, hydropower and geothermal can help reduce the

Table 5. Estimated parameters for single thresholds [DV = ED]

\begin{tabular}{|c|c|c|c|c|c|}
\hline & $\begin{array}{l}\text { Model } 1 \\
I Q=I Q_{A V G}\end{array}$ & $\begin{array}{c}\text { Model } 2 \\
\mathrm{IQ}=\mathrm{CC}\end{array}$ & $\begin{array}{c}\text { Model } 3 \\
\mathrm{IQ}=\mathrm{GE}\end{array}$ & $\begin{array}{c}\text { Model } 4 \\
\mathrm{IQ}=\mathrm{RQ}\end{array}$ & $\begin{array}{c}\text { Model } 5 \\
\text { IQ }=\text { RL }\end{array}$ \\
\hline Constant & $\begin{array}{l}3.056^{* * *} \\
(0.000)\end{array}$ & $\begin{array}{c}3.460 * \\
(0.091)\end{array}$ & $\begin{array}{l}3.807^{* * *} \\
(0.000)\end{array}$ & $\begin{array}{l}3.659 * * * \\
(0.000)\end{array}$ & $\begin{array}{l}3.867 * * * \\
(0.000)\end{array}$ \\
\hline GDP & $\begin{array}{l}0.493^{* * *} \\
(0.000)\end{array}$ & $\begin{array}{l}0.596 * * * \\
(0.000)\end{array}$ & $\begin{array}{l}0.578^{* * *} \\
(0.000)\end{array}$ & $\begin{array}{l}0.556^{* * *} \\
(0.000)\end{array}$ & $\begin{array}{l}0.589 * * * \\
(0.000)\end{array}$ \\
\hline $\mathrm{RE}$ & $\begin{array}{l}-0.397^{* * *} \\
(0.000)\end{array}$ & $\begin{array}{l}-0.397 * * * \\
(0.000)\end{array}$ & $\begin{array}{l}-0.398 * * * \\
(0.000)\end{array}$ & $\begin{array}{l}-0.396 * * * \\
(0.000)\end{array}$ & $\begin{array}{l}-0.403 * * * \\
(0.000)\end{array}$ \\
\hline $\mathrm{GDP}^{2} \mathrm{I}\left(\lambda_{1} \leq \mathrm{IQ}\right)$ & $\begin{array}{l}0.007^{* * *} \\
(0.008)\end{array}$ & $\begin{array}{c}0.006^{* *} \\
(0.011)\end{array}$ & $\begin{array}{l}0.008^{* * *} \\
(0.002)\end{array}$ & $\begin{array}{l}0.007^{* * *} \\
(0.004)\end{array}$ & $\begin{array}{c}0.006^{* *} \\
(0.016)\end{array}$ \\
\hline $\operatorname{GDP}^{2} \mid\left(\lambda_{2}>1 Q\right)$ & $\begin{array}{c}0.005^{* *} \\
(0.031)\end{array}$ & $\begin{array}{l}0.007^{* * *} \\
(0.005)\end{array}$ & $\begin{array}{c}0.006 * * \\
(0.014)\end{array}$ & $\begin{array}{c}0.006 * * \\
(0.010)\end{array}$ & $\begin{array}{l}0.005^{* *} \\
(0.027)\end{array}$ \\
\hline
\end{tabular}

Note: The $\mathrm{p}$-values are reported in parentheses. *,**, and $* * *$ denote $10 \%, 5 \%$, and $1 \%$ level of significance, respectively. DV, ED, GDP, $R E, C C, G E, R Q, R L$, and $I_{A V G}$ stand for dependent variable, environmental degradation, income, renewable energy, control of corruption, government effectiveness, regulatory quality, rule of law and average institutional quality, respectively. 
growth of carbon intensity and also provide sustainable energy services (Shafiei \& Salim, 2014).

Moving on to our main interest, the findings indicate that all five proxies for institutional quality in Model 1 until Model 5 have positive signs and are statistically significant in the first regime, or when IQ is below the threshold point. These estimates are substantially lower than those by Sharma (2011) for developed and developing countries (i.e. 13.189), Pao and Tsai (2011) for BRIC (Brazil, Russia, India and China) and Balsalobre-Lorente, Shahbaz, Roubaud and Farhani (2018) for European countries (i.e. 0.019). For example, the first regime estimates that the coefficient in Model 2 is 0.006 which implies that ED increases by $0.006 \%$ with an increase of $1 \%$ in $\mathrm{GDP}^{2}$ for countries that have CC of less than or equals to $0.142 \%$. As for the second regime (or when IQ is above the threshold point), we find that the coefficient estimates of GDP2 are positive and significant in all models. Our findings of single threshold effect of institutional quality on $\mathrm{GDP}^{2}$ values show that the two regime coefficients below or above the threshold value are positive and statistically significant at conventional level.

These empirical results suggest a noteworthy point that GDP2 is ineffective in reducing environmental degradation, or EKC is not valid. This issue explains that lack of enforcement of rules and regulations has significantly aggravated environmental quality, even at the higher level of income which contradicts what EKC predicted. Since in our dataset, 74 out of 99 countries are developing countries, it is conceivable that the increase in income may not be fully capable to mitigate environmental degradation in the absence of strong institutional quality as the case of most developing countries might be dominating the effect. For instance, India has a number of environmental policies, such as the Water Act of 1974 and Air Act of 1981 which deals with the increasingly hazardous pollution levels (Chen \& Lees, 2018). However, these regulations are not positive or very effective. The next analysis is to split the sample countries into developing and developed countries.

Although the full sample has been divided, the evidence of single threshold effect of IQ is still similar in both developed and developing countries as shown in Table 6. For developing countries, the F-statistic of 0.179 shows that the single thresholds are statistically significant as it is higher than the critical values for all models. This implies that there is evidence of single threshold effect of IQ on GDP2 for developing countries. Likewise, for developed countries, the F-statistic also shows that the single threshold is significant since it is higher that the critical values. Therefore, we focus on the single threshold model for the rest of the estimation analysis.

In developed countries, the results reported on the left-hand side of Table 7 reveal that the estimated coefficients of GDP ${ }^{2}$ is positive for IQ below the threshold point, but turn out to be negative after the threshold point. In other words, when IQ in the developed countries is lower than or equals to the threshold point (i.e. 1.142 as per Table 6), improvement in income (or $\mathrm{GDP}^{2}$ ) will still be unable to reduce environmental degradation. A $1 \%$ increase in income will deteriorate environmental quality on average by $0.67 \%$, or $0.45 \%$ in the case of high corruption, $1.35 \%$ in the case of government ineffectiveness, $0.86 \%$ in the case of poor regulatory quality and $0.31 \%$ in the case of weak rule of law. However, if the institutional quality is higher than the threshold point of developed countries, improvement in income could protect the environmental quality 
Tajul Ariffin Masron and Yogeeswari Subramaniam

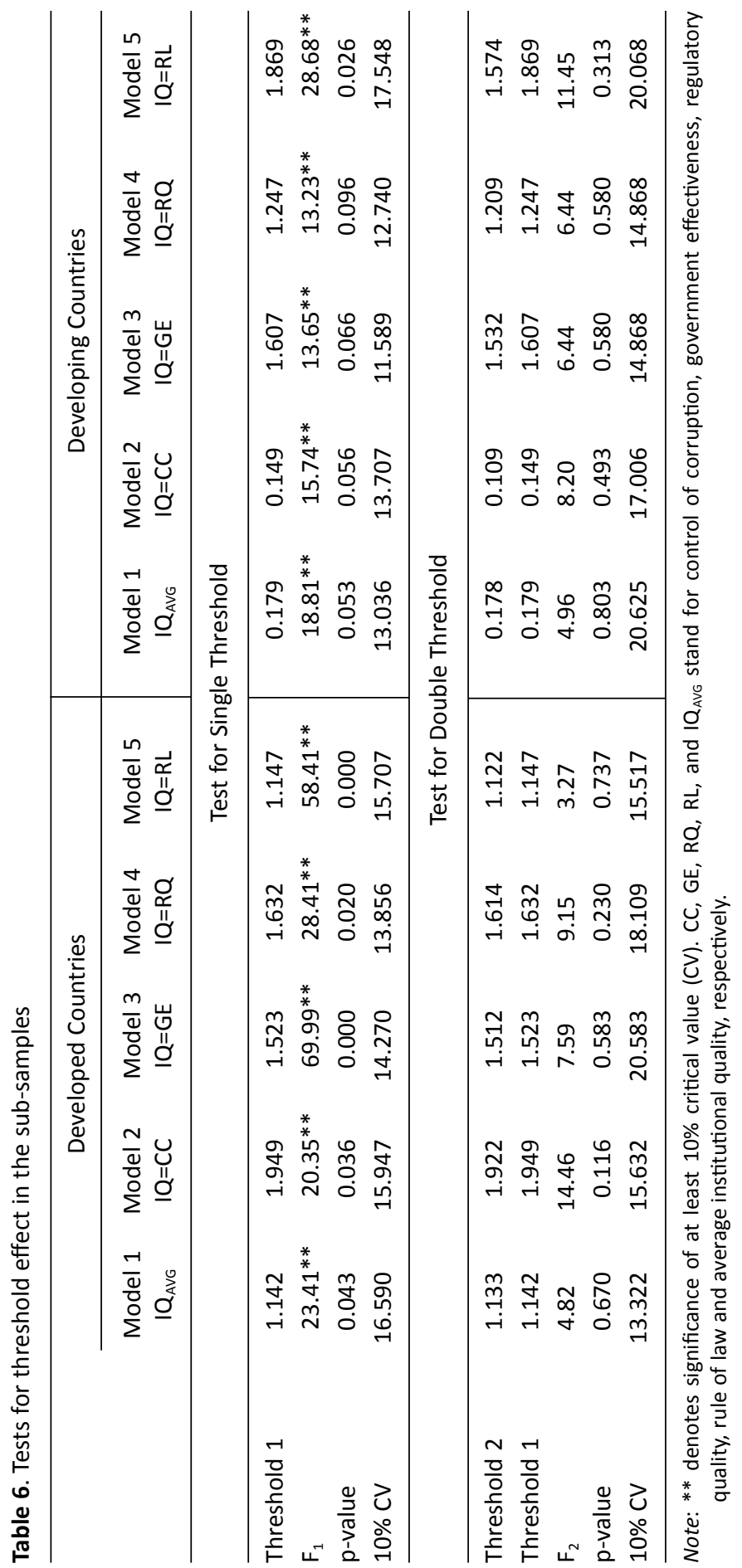


Threshold Effect of Institutional Quality and the Validity of Environmental Kuznets Curve

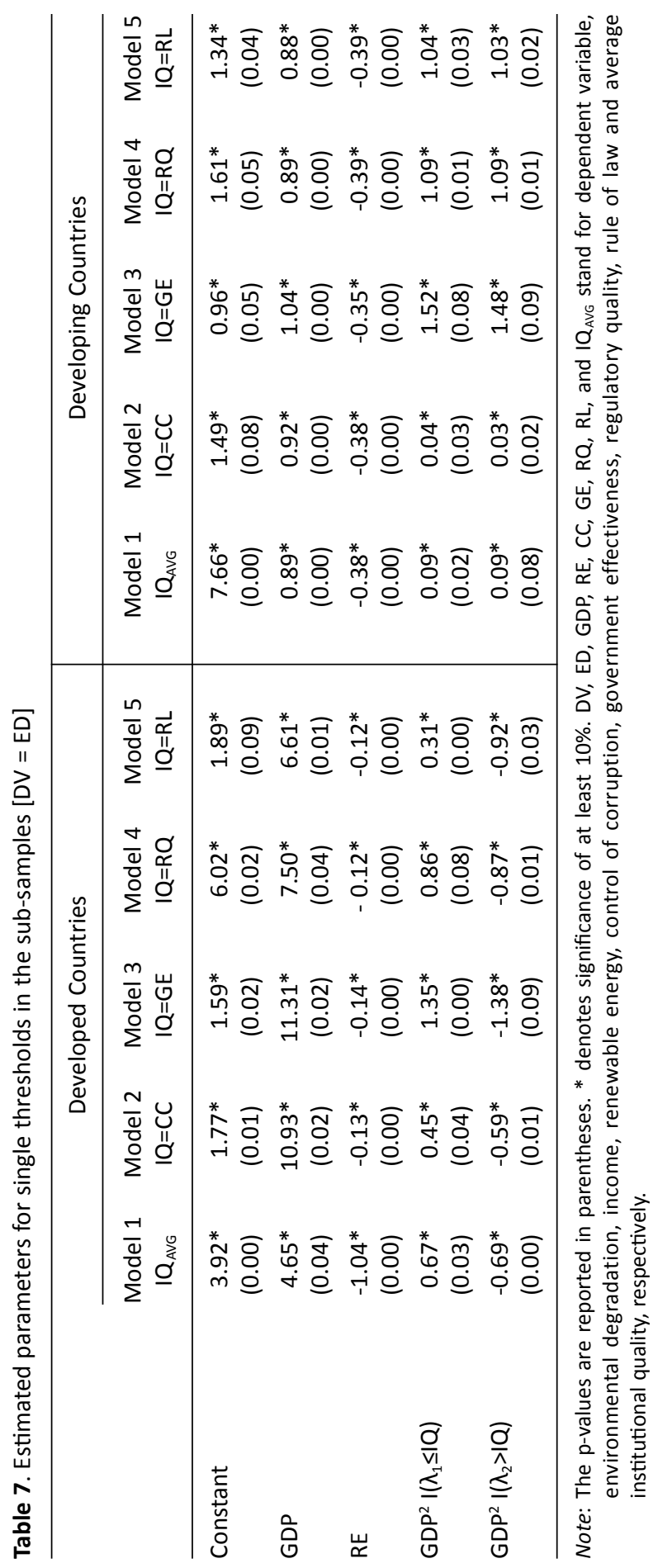


from deteriorating further. This indicates that even in the case of highly developed countries with relatively among the best IQ level in the world, a mere weakness in IQ level will open the door for environmental destruction. Only those countries with the best IQ or surpass the threshold IQ are capable to fully protect their environment.

For the developing countries case, the results are similar to the full sample case where being the countries with poor IQ level, the door for environmental destruction is even larger as reflected in the positive effect of GDP2 below the threshold point, which is 0.179 for $I Q_{A V G}, 0.149$ for $C C, 1.607$ for $G E, 1.247$ for $R Q$ and 1.869 for RL (see Table 6). The effect of $\mathrm{GDP}^{2}$ remains positive although it is slightly less destructive when IQ is better, or above the threshold point. At this stage, we observe that EKC is valid only in the case of developed countries with high institutional quality level. For the rest, namely developed countries with weak institutional quality, and developing countries, regardless of the level of institutional quality, EKC in general does not hold.

For further analysis, we performed a robustness check by incorporating foreign direct investment, trade, urbanisation and population growth in the threshold specification for developed and developing countries. Table 8 shows the results of the F-statistics for the single and double thresholds effect together with their bootstrap p-values. For the case of a single threshold, all five models display strong evidence of a threshold and it is higher than the critical value for both developed and developing countries. However, the tests for double threshold effect are insignificant, which indicates that the threshold effect does not exist. Hence, this confirms the validity of the single threshold.

Table 9 presents the estimated coefficients based on OLS for both developed and developing countries. The result for developed countries shows that GDP has a significantly positive relationship with environmental degradation in the first regime. In the second regime, when IQ is above the threshold point, GDP2 and environmental degradation have significantly negative relationship. The validity of the EKC is further substantiated in developed countries. On the other hand, for the case of developing countries, both GDP ${ }^{2}$ for below and above the threshold point show positive signs. This shows that EKC is invalid and high income fails to be converted fully to environmentprotecting activities. Even in the case of developing countries with high IQ, that high IQ may still be considered as low from world perspective and therefore, greatly offers rentseeking opportunities.

It has been found that FDI has a significant negative impact on environmental degradation which is in line with Cheung and Lin (2004), Mielnik and Goldemberg (2002), Stretesky and Lynch (2009) and Zugravu-Soilita (2017). Accordingly, it indicates the existence of the pollution halo hypothesis that FDI can help to reduce environmental pollution. The inflow of FDI leads to an improvement in environmental quality due to the usage of more efficient production technology. In this case, it is suggested that countries should attract large quantities of FDI projects to promote better environmental quality. Likewise, trade has a significant negative impact on environmental degradation for both developed and developing countries. This finding is similar to those obtained by Rezek and Rogers (2008) for industrialised countries, Lau et al. (2014) for Malaysia and Dogan and Seker (2016) for developed and developing countries. As discussed in the literature review section, this finding may be due to the presence of techniques and composition effects. 


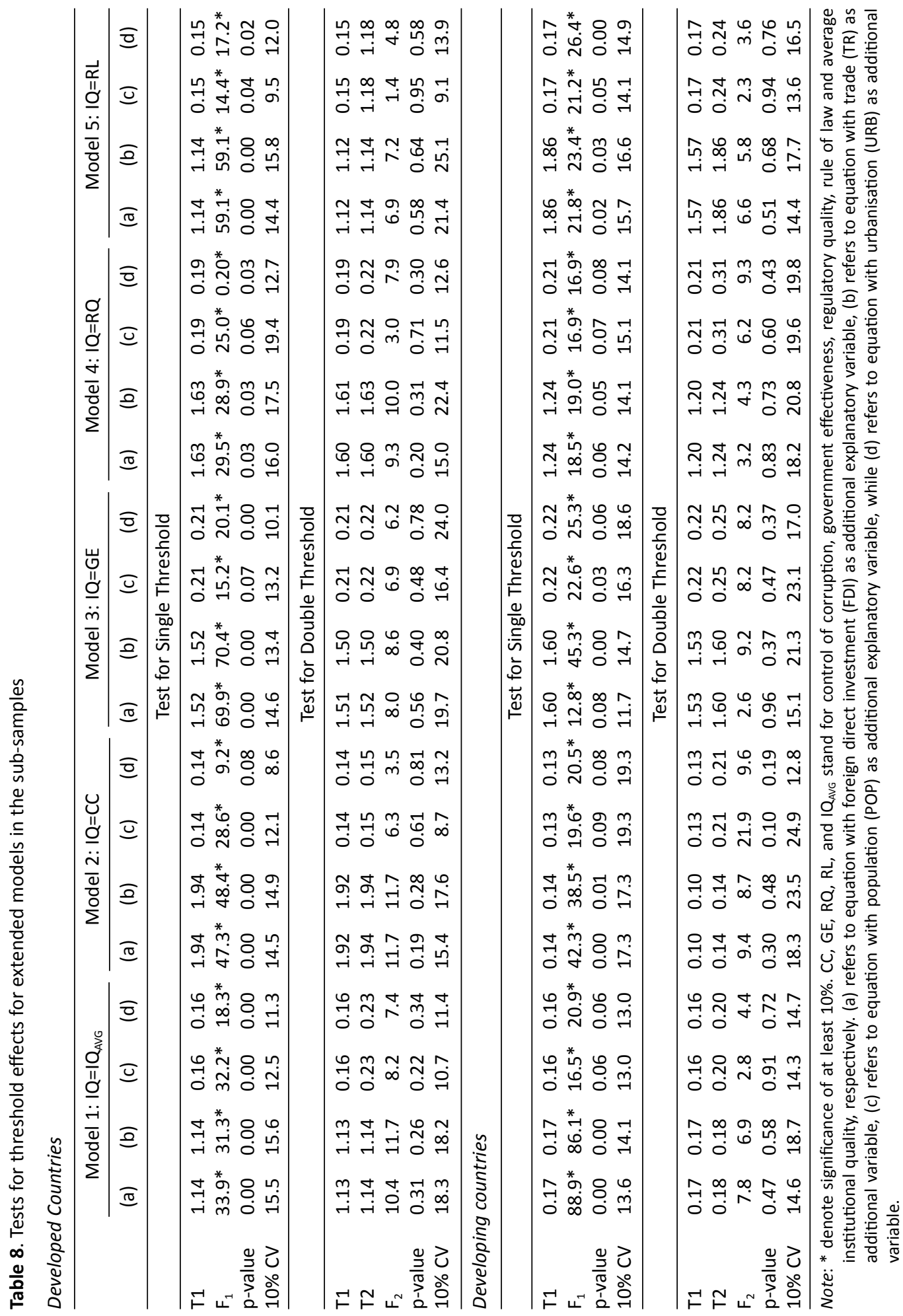




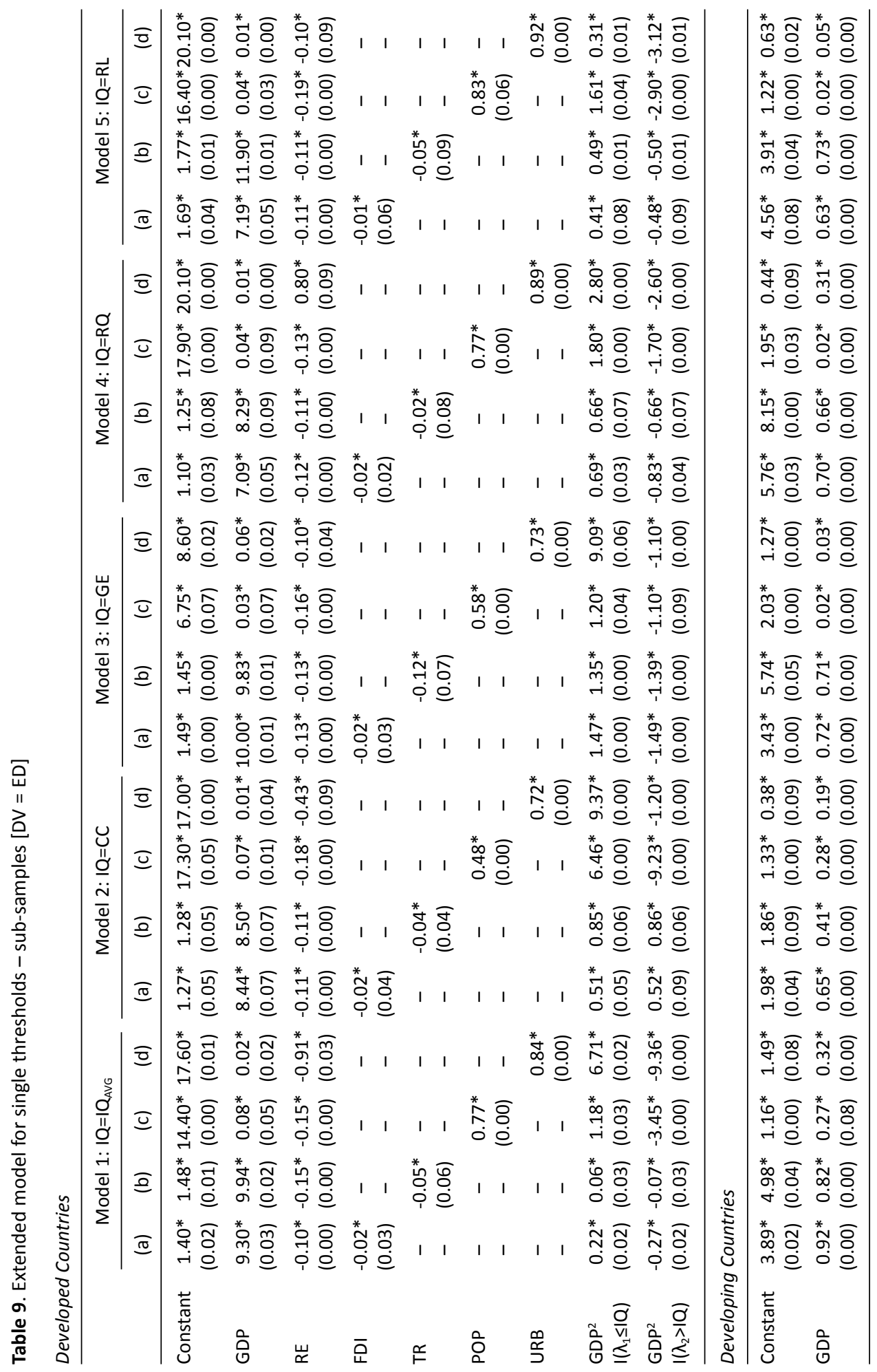




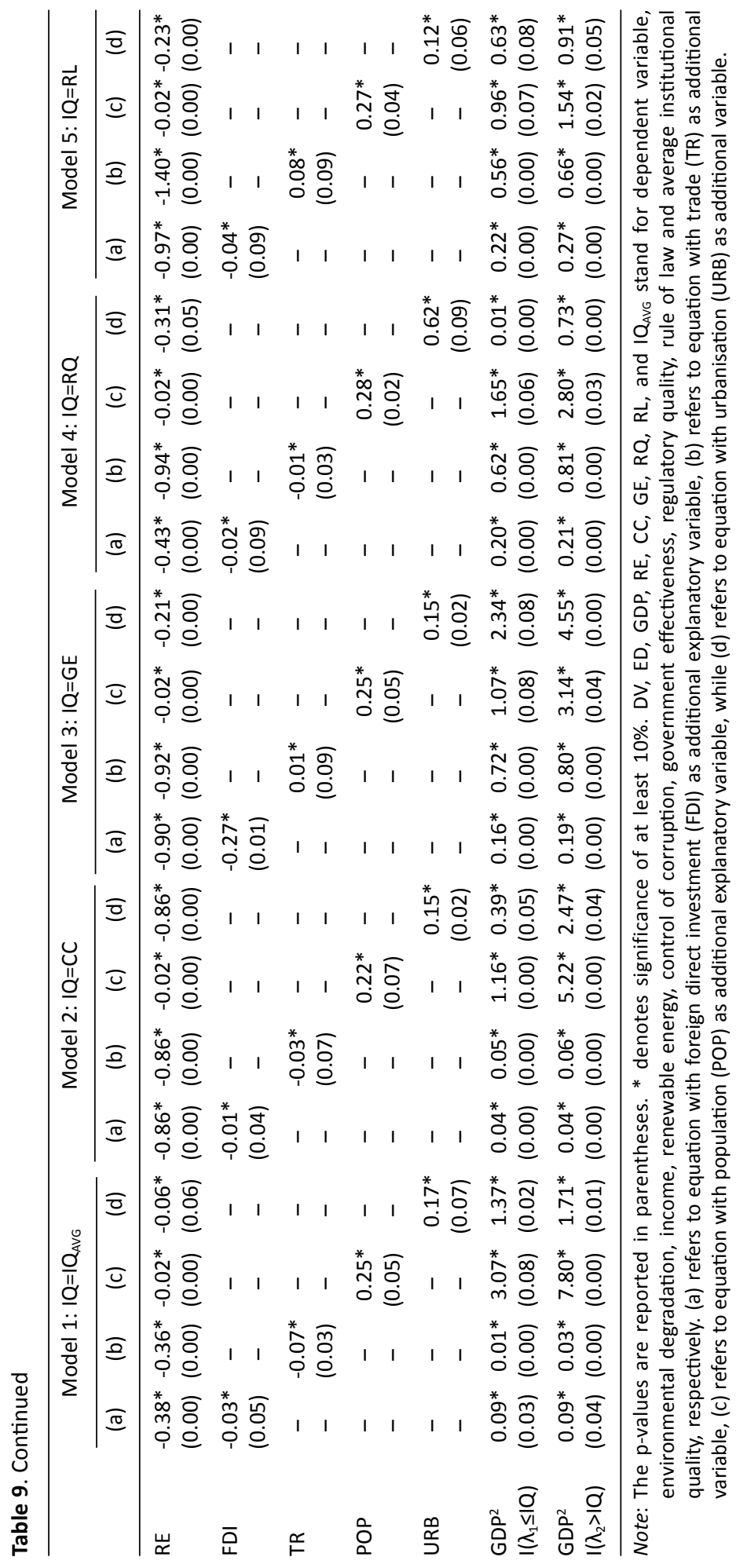


Besides that, this study finds that population growth increases environmental degradation in both developed and developing countries. This finding suggests that population growth may lead to use of greater amounts of resources to assist their basic necessities and livelihoods. As a result, it will generate a negative impact on the environment by offering various types of destruction on it (such as climate change, biodiversity loss and pollution). Our estimates are close to the ones reported by Hafeez et al. (2018), Hossain (2011), Liddle and Lung (2010), Paramati et al. (2018) and Zhang and Lin (2012).

Based on the analysis, urbanisation has been found to have a positive significant impact on environmental degradation, which implies that as urbanisation increases, the destruction level in developing and developed countries also rises, simultaneously. Although higher levels of industrialisation in urban areas create jobs and encourage modernisation, it will also increase emission. Our finding is consistent with the findings from researchers such as Al-Mulali and Ozturk (2016), Liu and Bae (2018), Munir and Ameer (2018) and Zhang and Zhou (2016).

Finally, we also examine the threshold model by incorporating all control variables in the model at once. Generally, the effect of income on environmental degradation is maintained. To conserve space, the results are displayed in Appendix A. To conclude, it can be said that EKC is only valid in the case of developed countries with good institutional qualities only.

\section{Conclusion}

The effectiveness of income in reducing environmental degradation remains as an unresolved issue as described by mixed results of past studies. Expecting the potential poor institutional quality as the conditional factor, applying data from 99 countries covering through 2008-2016, this study examines the existence of threshold effect of institutional quality on income-environment nexus, or to be precise, the EKC hypothesis. First of all, the empirical results indicate that there is a significant single institutional threshold in the environmental degradation-income nexus. Secondly, we also observe that in the presence of imperfect institutional quality, income seems to be ineffective to promote quality environment as the effects of higher income (represented by GDP2) are no longer negative in both regimes. Thirdly, since income is likely ineffective to reduce environmental degradation in the presence of imperfect institutional quality, better institutional quality tends to help maintain the environmental quality. In summary, this study tends to invalidate the existence of EKC in the presence of imperfect institutional quality with exception to the case of developed countries with high quality of institution.

In terms of policy implication, policy makers should give equal attention to the efforts on promoting economic growth and improving institutional quality. This is because weak formal institutional qualities will prevent high income to effectively protect environmental degradation, mainly in developing countries and also in some developed countries. Accordingly, as countries strive towards higher economic growth, governments should develop stronger institutions such as improving government efficiency, transparency and enhancing the rule of law in order to assure the large 
amount of allocation (due to high income) for environmental protecting efforts to be fruitful. For instance, setting up more effective anti-corruption agencies to enforce the rule and prosecute corrupted people by imposing stricter environmental laws and enforcement in order to strengthen environmental qualities (Law, Kutan, \& Naseem, 2018; Olayungbo \& Adediran, 2017).

Concerning foreign direct investment and trade, both signal a negative effect and are likely to support the effort of host countries in preserving environmental quality. More pro-environment FDI should be encouraged to inflow and pro-environment quality trading goods must be targeted. Thereby, governing bodies need to eliminate or minimise any legal and non-legal obstacles that discourage multinational corporations from coming. Nevertheless, policies on flows of goods should be made more stringent to ensure only goods that are compatible with the environment should be allowed. Moreover, governments should design and implement effective policies to promote investment in renewable technologies and energy conservation (e.g. stability of energy price, affordability and reliability) to promote more demand for renewable energy and eventually, improve the quality of the environment. Such government policies will encourage a high capacity for renewable energy investment, reduce obstacles (e.g. lack of cost, regulation and issues) and opportunities (e.g. energy security and new technology use) to the growth of renewable energy use. Enhancement of basic education and formulation of appropriate policy for long term urban planning help to increase environmental awareness, skills to promote environmental quality, construction of new 'green' residential parks and necessary infrastructure to minimise the adverse environmental impact of population growth or urbanisation.

Despite these important findings, there is a possibility of having a different threshold effect of institutional quality on the income-environment nexus in each developing and developed nation. Thus, future researchers need to broaden the analysis to include time series data such as for individual developing countries. This is because most of the developing countries are assumed to be similar to each other, but in reality, these countries may have their own unique policies and socio-economic characteristics. As a result, proper planning to spur sustainable environmental management and good environmental quality can be proposed strategically by evaluating these economies individually.

\section{References}

Aidt, T.S. (2009). Corruption, institutions, and economic development. Oxford Review of Economic Policy, 25(2), 271-291. https://doi.org/10.1093/oxrep/grp012

Aklin, M. (2016). Re-exploring the trade and environment nexus through the diffusion of pollution. Environmental and Resource Economics, 64(4), 663-682. https://doi.org/10.1007/ s10640-015-9893-1

Al-Mulali, U., \& Ozturk, I. (2016). The investigation of environmental Kuznets curve hypothesis in the advanced economies: The role of energy prices. Renewable and Sustainable Energy Reviews, 54(February), 1622-1631. https://doi.org/10.1016/j.rser.2015.10.131

Ampratwum, E.F. (2008). The fight against corruption and its implications for development in developing and transition economies. Journal of Money Laundering Control, 11(1), 76-87. https://doi.org/10.1108/13685200810844514 
Ang, J.B. (2007). $\mathrm{CO}_{2}$ emissions, energy consumption, and output in France. Energy Policy, 35(10), 4772-4778. https://doi.org/10.1016/j.enpol.2007.03.032

Apergis, N., Payne, J.E., Menyah, K., \& Wolde-Rufael, Y. (2010). On the causal dynamics between emissions, nuclear energy, renewable energy, and economic growth. Ecological Economics, 69(11), 2255-2260. https://doi.org/10.1016/j.ecolecon.2010.06.014

Balsalobre-Lorente, D., Shahbaz, M., Roubaud, D., \& Farhani, S. (2018). How economic growth, renewable electricity and natural resources contribute to $\mathrm{CO}_{2}$ emissions? Energy Policy, 113(February), 356-367. https://doi.org/10.1016/j.enpol.2017.10.050

Banta, B.R. (2008). Just war theory and the $2003 \mathrm{Iraq}$ war forced displacement. Journal of Refugee Studies, 21(3), 261-284. https://doi.org/10.1093/jrs/fen027

Begum, R.A., Sohag, K., Abdullah, S.M.S., \& Jaafar, M. (2015). $\mathrm{CO}_{2}$ emissions, energy consumption, economic and population growth in Malaysia. Renewable and Sustainable Energy Reviews, 41(January), 594-601. https://doi.org/10.1016/j.rser.2014.07.205

Belaid, F., \& Youssef, M. (2017). Environmental degradation, renewable and non-renewable electricity consumption, and economic growth: Assessing the evidence from Algeria. Energy Policy, 102(March), 277-287. https://doi.org/10.1016/j.enpol.2016.12.012

Bento, J.P.C., \& Moutinho, V. (2016). $\mathrm{CO}_{2}$ emissions, non-renewable and renewable electricity production, economic growth, and international trade in Italy. Renewable and Sustainable Energy Reviews, 55(March), 142-155. https://doi.org/10.1016/j.rser.2015.10.151

Berdiev, A.N., Kim, Y., \& Chang, C.-P. (2013). Remittances and corruption. Economics Letters, 118(1), 182-185. https://doi.org/10.1016/j.econlet.2012.10.008

Bhattarai, M., \& Hammig, M. (2004). Governance, economic policy, and the environmental Kuznets curve for natural tropical forests. Environment and Development Economics, 9(3), 367-382. https://doi.org/10.1017/S1355770X03001293.

Bilgili, F., Kocak, E., \& Bulut, U. (2016). The dynamic impact of renewable energy consumption on $\mathrm{CO}_{2}$ emissions: A revisited environmental Kuznets curve approach. Renewable and Sustainable Energy Reviews, 54(February), 838-845. https://doi.org/10.1016/j.rser.2015.10.080.

Boluk, G., \& Mert, M. (2014). Fossil \& renewable energy consumption, GHGs (greenhouse gases) and economic growth: Evidence from a panel of EU (European Union) countries. Energy, 74(September), 439-446. https://doi.org/10.1016/j.energy.2014.07.008

Chen, G.C., \& Lees, C. (2018). The new, green, urbanization in China: Between authoritarian environmentalism and decentralization. Chinese Political Science Review, 3(2), 212-231. https://doi.org/10.1007/s41111-018-0095-1

Cheung, K.Y., \& Lin, P. (2004). Spillover effects of FDI on innovation in China: Evidence from the provincial data. China Economic Review, 15(1), 25-44. https://doi.org/10.1016/S1043951X(03)00027-0

Cole, M.A., \& Elliott, R.J. (2005). FDI and the capital intensity of "dirty" sectors: a missing piece of the pollution haven puzzle. Review of Development Economics, 9(4), 530-548. https://doi. org/10.1111/j.1467-9361.2005.00292.x

Copeland, B.R., \& Taylor, M.S. (1995). Trade and the environment: A partial synthesis. American Journal of Agricultural Economics, 77(3), 765-771. https://doi.org/10.2307/1243249

Dasgupta, S., Laplante, B., Wang, H., \& Wheeler, D. (2002). Confronting the environmental Kuznets curve. Journal of Economic Perspectives, 16(1), 147-168. https://doi.org/10.1257/ 0895330027157

Del Monte, A., \& Papagni, E. (2001). Public expenditure, corruption, and economic growth: The case of Italy. European Journal of Political Economy, 17(1), 1-16. https://doi.org/10.1016/ S0176-2680(00)00025-2

Dillon, J., Ekmekji, K., Feighery, A., Garrett, R., Gray, M., Johnson, T., ... Reilly, K. (2006). Corruption \& the environment. In a project for Transparency International, Environmental Science and Policy Workshop, Columbia University, School of International \& Public Affairs. 
Dogan, E., \& Seker, F. (2016). The influence of real output, renewable and non-renewable energy, trade and financial development on carbon emissions in the top renewable energy countries. Renewable and Sustainable Energy Reviews, 60(July), 1074-1085. https://doi.org/10.1016/j. rser.2016.02.006

Ehrhardt-Martinez, K., Crenshaw, E.M., \& Jenkins, J.C. (2003). Deforestation and the environmental Kuznets curve: A cross-national investigation of intervening mechanisms. Social Science Quarterly, 83(1), 226-243. https://doi.org/10.1111/1540-6237.00080

Elum, Z.A., \& Momodu, A.S. (2017). Climate change mitigation and renewable energy for sustainable development in Nigeria: A discourse approach. Renewable and Sustainable Energy Reviews, 76(September), 72-80. https://doi.org/10.1016/j.rser.2017.03.040

Grossman, G.M., \& Krueger, A.B. (1995). Economic growth and the environment. The Quarterly Journal of Economics, 110(2), 353-377. https://doi.org/10.2307/2118443

Hafeez, M., Chunhui, Y., Strohmaier, D., Ahmed, M., \& Jie, L. (2018). Does finance affect environmental degradation: Evidence from One Belt and One Road Initiative region? Environmental Science and Pollution Research, 25(10), 9579-9592. https://doi.org/10.1007/s11356-0181317-7

Halicioglu, F., \& Ketenci, N. (2016). The impact of international trade on environmental quality: The case of transition countries. Energy, 109(August), 1130-1138. https://doi.org/10.1016/j. energy.2016.05.013

Hansen, B.E. (1999). Threshold effects in non-dynamic panels: Estimation, testing, and inference. Journal of Econometrics 93(2), 345-368. https://doi.org/10.1016/S0304-4076(99)00025-1

Heidari, H., Katircioğlu, S.T., \& Saeidpour, L. (2015). Economic growth, $\mathrm{CO}_{2}$ emissions, and energy consumption in the five ASEAN countries. International Journal of Electrical Power \& Energy Systems, 64(January), 785-791. https://doi.org/10.1016/j.ijepes.2014.07.081

Holtz-Eakin, D., \& Selden, T.M. (1995). Stoking the fires? $\mathrm{CO}_{2}$ emissions and economic growth. Journal of Public Economics, 57(1), 85-101. https://doi.org/10.1016/0047-2727(94)01449-X

Hossain, M.S. (2011). Panel estimation for $\mathrm{CO}_{2}$ emissions, energy consumption, economic growth, trade openness and urbanization of newly industrialized countries. Energy Policy, 39(11), 6991-6999. https://doi.org/10.1016/j.enpol.2011.07.042

Jebli, M.B., Youssef, S.B., \& Ozturk, I. (2016). Testing environmental Kuznets curve hypothesis: The role of renewable and non-renewable energy consumption and trade in OECD countries. Ecological Indicators, 60(January), 824-831. https://doi.org/10.1016/j.ecolind.2015.08.031

Kellenberg, D.K. (2009). An empirical investigation of the pollution haven effect with strategic environment and trade policy. Journal of International Economics, 78(2), 242-255. https:// doi.org/10.1016/j.jinteco.2009.04.004

Kotze, L.J. (2006). Improving unsustainable environmental governance in South Africa: The case for holistic governance. Potchefstroom Electronic Law Journal/Potchefstroomse Elektroniese Regsblad, 9(1), 1-44. https://doi.org/10.4314/pelj.v9i1.43452.

Lau, L.S., Choong, C.K., \& Eng, Y.K. (2014). Investigation of the environmental Kuznets curve for carbon emissions in Malaysia: Do foreign direct investment and trade matter? Energy Policy, 68(May), 490-497. https://doi.org/10.1016/j.enpol.2014.01.002

Law, S.H., Kutan, A.M., \& Naseem, N.A.M. (2018). The role of institutions in finance curse: Evidence from international data. Journal of Comparative Economics, 46(1), 174-191. https:// doi.org/10.1016/j.jce.2017.04.001

Lean, H.H., \& Smyth, R. (2010). $\mathrm{CO}_{2}$ emissions, electricity consumption and output in ASEAN. Applied Energy, 87(6), 1858-1864. https://doi.org/10.1016/j.apenergy.2010.02.003

Lee, C.C., \& Lee, J.-D. (2009). Income and $\mathrm{CO}_{2}$ emissions: Evidence from panel unit root and cointegration tests. Energy Policy 37(2), 413-423. https://doi.org/10.1016/j.enpol.2008.09.053

Leitão, N. (2010). Does trade help to explain tourism demand? The case of Portugal. Theoretical and Applied Economics, 3(3), 63-74. 
Liddle, B., \& Lung, S. (2010). Age-structure, urbanization, and climate change in developed countries: Revisiting STIRPAT for disaggregated population and consumption-related environmental impacts. Population and Environment, 31(5), 317-343. https://doi.org/10.1007/ s11111-010-0101-5

Liu, X., \& Bae, J. (2018). Urbanization and industrialization impact of $\mathrm{CO}_{2}$ emissions in China. Journal of Cleaner Production, 172(January), 178-186. https://doi.org/10.1016/j. jclepro.2017.10.156

Marquart-Pyatt, S. (2004). A cross-national investigation of deforestation, debt, state fiscal capacity, and the environmental Kuznets Curve. International Journal of Sociology, 34(1), 3351. https://doi.org/10.1080/00207659.2004.11043128

Mauro, P. (1998). Corruption and the composition of government expenditure. Journal of Public Economics, 69(2), 263-279. https://doi.org/10.1016/S0047-2727(98)00025-5

Mielnik, O., \& Goldemberg, J. (2002). Foreign direct investment and decoupling between energy and gross domestic product in developing countries. Energy Policy, 30(2), 87-89. https://doi. org/10.1016/S0301-4215(01)00080-5

Munir, K., \& Ameer, A. (2018). Effect of economic growth, trade openness, urbanization, and technology on environment of Asian emerging economies. Management of Environmental Quality: An International Journal, 29(3), 1123-1134. https://doi.org/10.1108/MEQ-05-20180087

Olayungbo, D.O., \& Adediran, K.A. (2017). Effects of Oil Revenue and Institutional Quality on Economic Growth with an ARDL Approach. Energy and Policy Research, 4(1), 44-54. https:// doi.org/10.1080/23815639.2017.1307146

Omri, A., Daly, S., Rault, C., \& Chaibi, A. (2015). Financial development, environmental quality, trade and economic growth: What causes what in MENA countries? Energy Economics, 48(March), 242-252. https://doi.org/10.1016/j.eneco.2015.01.008

Pao, H.T. \& Tsai, C.M. (2011). Multivariate granger causality between $\mathrm{CO}_{2}$ emissions, energy consumption, FDI (foreign direct investment) and GDP (gross domestic product): Evidence from a panel of BRIC (Brazil, Russian Federation, India, and China) countries. Energy, 36(1), 685-693. https://doi.org/10.1016/j.energy.2010.09.041

Paramati, S.R., Alam, M.S., \& Lau, C.K.M. (2018). The effect of tourism investment on tourism development and $\mathrm{CO}_{2}$ emissions: Empirical evidence from the EU nations. Journal of Sustainable Tourism, 26(9), 1587-1607. https://doi.org/10.1080/09669582.2018.1489398

Pellegrini, L., \& Gerlagh, R. (2006). Corruption, democracy, and environmental policy: An empirical contribution to the debate. The Journal of Environment \& Development, 15(3), 332-354. https://doi.org/10.1177/1070496506290960

Reppelin-Hill, V. (1999). Trade and environment: An empirical analysis of the technology effect in the steel industry. Journal of Environmental Economics and Management, 38(3), 283-301. https://doi.org/10.1006/jeem.1999.1085

Rezek, J.P., \& Rogers, K. (2008). Decomposing the $\mathrm{CO}_{2}$-income tradeoff: An output distance function approach. Environment and Development Economics, 13(4), 457-473. https://doi. org/10.1017/S1355770X08004385

Robbins, P. (2000). The rotten institution: Corruption in natural resource management. Political Geography, 19(4), 423-443. https://doi.org/10.1016/S0962-6298(99)00087-6

Roberts, J.T., \& Grimes, P.E. (1997). Carbon intensity and economic development 1962-1991: A brief exploration of the environmental Kuznets curve. World Development, 25(2), 191-198. https://doi.org/10.1016/S0305-750X(96)00104-0

Rodrik, D., Subramanian, A., \& Trebbi, F. (2004). Institutions rule: The primacy of institutions over geography and integration in economic development. Journal of Economic Growth, 9(2), 131165. https://doi.org/10.1023/B:JOEG.0000031425.72248.85 
Rose-Ackerman, S., \& Palifka, B.J. (2016). Corruption and government: Causes, consequences, and reform. Cambridge, UK: Cambridge University Press.

Saboori, B., Sulaiman, J., \& Mohd, S. (2012). Economic growth and $\mathrm{CO}_{2}$ emissions in Malaysia: A cointegration analysis of the environmental Kuznets curve. Energy Policy 51(December), 184191. https://doi.org/10.1016/j.enpol.2012.08.065

Sari, R., \& Soytas, U. (2007). The growth of income and energy consumption in six developing countries. Energy Policy, 35(2), 889-898. https://doi.org/10.1016/j.enpol.2006.01.021

Shafiei, S., \& Salim, R.A. (2014). Non-renewable and renewable energy consumption and $\mathrm{CO}_{2}$ emissions in OECD countries: A comparative analysis. Energy Policy, 66(March), 547-556. https://doi.org/10.1016/j.enpol.2013.10.064

Shafik, N. (1994). Economic development and environmental quality: An econometric analysis. Oxford Economic Papers, 46(S1), 757-773. https://doi.org/10.1093/oep/46. Supplement_1.757

Shahbaz, M., Nasreen, S., Ahmed, K., \& Hammoudeh, S. (2017). Trade openness-carbon emissions nexus: The importance of turning points of trade openness for country panels. Energy Economics, 61(January), 221-232. https://doi.org/10.1016/j.eneco.2016.11.008

Shandra, J.M., London, B., Whooley, O.P., \& Williamson, J.B. (2004). International nongovernmental organizations and carbon dioxide emissions in the developing world: A quantitative, cross-national analysis. Sociological Inquiry, 74(4), 520-545. https://doi.org/10.1111/j.1475682X.2004.00103.x

Sharma, S.S. (2011). Determinants of carbon dioxide emissions: Empirical evidence from 69 countries. Applied Energy, 88(1), 376-382. https://doi.org/10.1016/j.apenergy.2010.07.022

Stern, D.I. (2004). The rise and fall of the environmental Kuznets curve. World Development, 32(8), 1419-1439. https://doi.org/10.1016/j.worlddev.2004.03.004

Stretesky, P.B., \& Lynch, M.J. (2009). A cross-national study of the association between per capita carbon dioxide emissions and exports to the United States. Social Science Research, 38(1), 239-250. https://doi.org/10.1016/j.ssresearch.2008.08.004

Transparency International. (2016). Corruption perception index 2016. Retrieved from https:// www.transparency.org/news/feature/corruption_perceptions_index_2016

Ugur, M. (2014). Corruption's direct effects on per-capita income growth: A meta-analysis. Journal of Economic Surveys, 28(3), 472-490. https://doi.org/10.1111/joes.12035

Ugur, M., \& Dasgupta, N. (2011). Evidence on the economic growth impacts of corruption in lowincome countries and beyond: A systematic review. London: EPPI-Centre, SSRU. Institute of Education, University of London.

Welsch, H. (2004). Corruption, growth, and the environment: A cross-country analysis. Environment and Development Economics 9(5), 663-693. https://doi.org/10.1017/S1355770X 04001500

Winbourne, S. (2002). Corruption and the environment. Washington, DC: USAID and Management Systems International.

World Bank. (2017a). World development indicators. Retrieved from http://data.worldbank.org/ indicator

World Bank. (2017b). Worldwide governance indicators. Retrieved from http://data.worldbank. org/data-catalog/worldwide-governance-indicators

Zhang, C., \& Lin, Y. (2012). Panel estimation for urbanization, energy consumption and $\mathrm{CO}_{2}$ emissions: A regional analysis in China. Energy Policy, 49(October), 488-498. https://doi. org/10.1016/j.enpol.2012.06.048

Zhang, C., \& Zhou, X. (2016). Does foreign direct investment lead to lower $\mathrm{CO} 2$ emissions? Evidence from a regional analysis in China. Renewable and Sustainable Energy Reviews, 58(May), 943-951. https://doi.org/10.1016/j.rser.2015.12.226 
Zhang, Y.-J., Jin, Y.-L., Chevallier, J., \& Shen, B. (2016). The effect of corruption on carbon dioxide emissions in APEC countries: A panel quantile regression analysis. Technological Forecasting and Social Change, 112(November), 220-227. https://doi.org/10.1016/j.techfore.2016.05.027

Zoundi, Z. (2017). CO2 emissions, renewable energy and the environmental Kuznets curve, a panel cointegration approach. Renewable and Sustainable Energy Reviews, 72(May), 10671075. https://doi.org/10.1016/j.rser.2016.10.018

Zugravu-Soilita, N. (2017). How does foreign direct investment affect pollution? Toward a better understanding of the direct and conditional effects. Environmental and Resource Economics, 66(2), 293-338. https://doi.org/10.1007/s10640-015-9950-9 
Threshold Effect of Institutional Quality and the Validity of Environmental Kuznets Curve

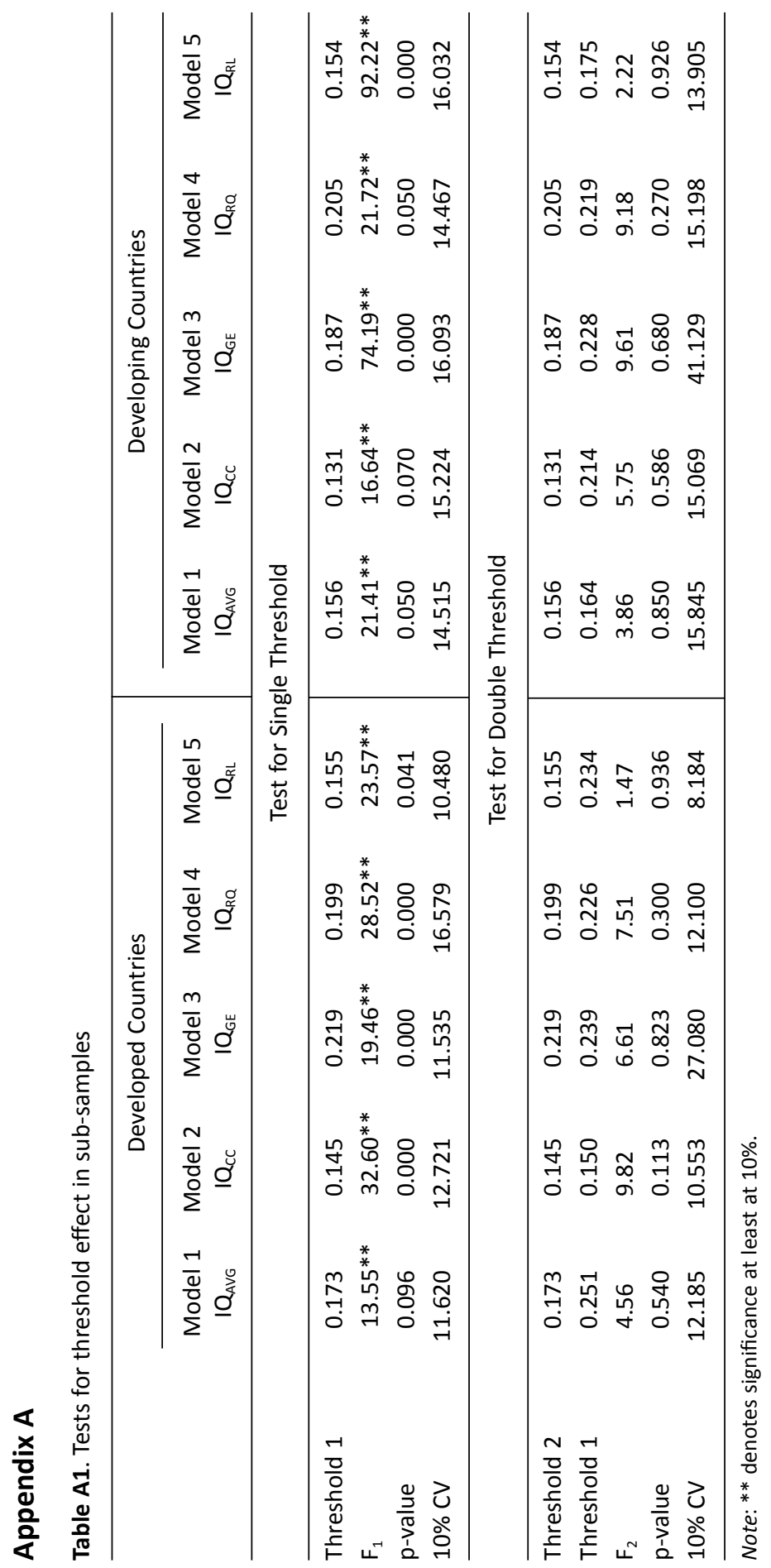




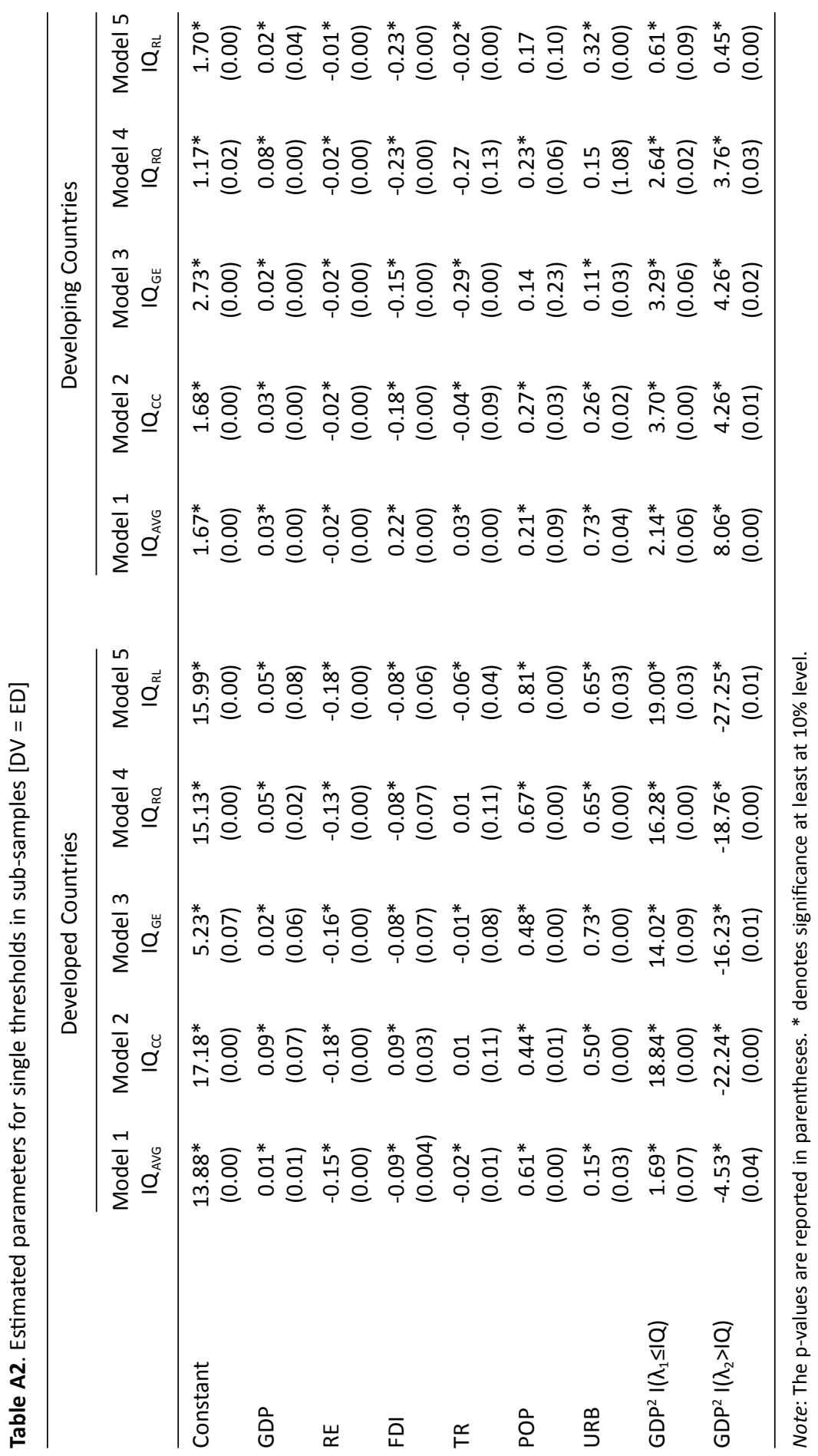

